\title{
Reversal of Multidrug Resistance in Cancer by Multi-Functional Flavonoids
}

\section{OPEN ACCESS}

Edited by:

Simona Rapposelli,

University of Pisa, Italy

Reviewed by:

Qingbin Cui,

St. John's University, United States

Loretta Lazzarato,

University of Turin, Italy

Marialessandra Contino,

University of Bari Aldo Moro, Italy

*Correspondence:

Fangxuan Han

hfx1223@163.com

Ren-Wang Jiang

trwjiang@jnu.edu.cn

Specialty section:

This article was submitted to Pharmacology of Anti-Cancer Drugs,

a section of the journal

Frontiers in Oncology

Received: 18 April 2019

Accepted: 23 May 2019

Published: 12 June 2019

Citation:

Ye Q, Liu K, Shen Q, Li Q, Hao J, Han F and Jiang R-W (2019) Reversal of Multidrug Resistance in Cancer by

Multi-Functional Flavonoids.

Front. Oncol. 9:487.

doi: 10.3389/fonc.2019.00487

\author{
Qingmei Ye ${ }^{1}$, Kai Liu ${ }^{1}$, Qun Shen ${ }^{1}$, Qingyue $\mathrm{Li}^{1}$, Jinghui Hao ${ }^{2}$, Fangxuan Han ${ }^{1 *}$ and \\ Ren-Wang Jiang ${ }^{3 *}$ \\ ${ }^{1}$ Hainan General Hospital, Haikou, China, ${ }^{2}$ Jiaozuo Second People's Hospital, Jiaozuo, China, ${ }^{3}$ Guangdong Province Key \\ Laboratory of Pharmacodynamic Constituents of TCM and New Drugs Research, Cooperative Laboratory of Traditional \\ Chinese Medicine Modernization and Innovative Drug Development of Chinese Ministry of Education, Jinan University, \\ Guangzhou, China
}

Multidrug resistance (MDR) resulting from different defensive mechanisms in cancer is one of the major obstacles of clinical treatment. To circumvent MDR many reversal agents have been developed, but most of them fail in clinical trials due to severely adverse effects. Recently, certain natural products have been reported to overcome MDR, including flavonoids which are abundant in plants, foods, and herbs. The structure of flavonoids can be abbreviated as C6-C3-C6 (C for carbon), and further categorized into flavonoids, iso-flavonoids and neo-flavonoids, according to their structural backbones. Flavonoids possess multiple bioactivities, and a growing body of research has indicated that both flavonoids and iso-flavonoids can either kill or re-sensitize conventional chemotherapeutics to resistant cancer cells. Here, we summarize the research and discuss the underlying mechanisms, concluding that these flavonoids do not function as specific regulators of target proteins, but rather as multi-functional agents that negatively regulate the key factors contributing to MDR.

Keywords: multidrug resistance, natural products, flavonoids, overcome, cancer, drug discovery

\section{INTRODUCTION}

Multidrug resistance (MDR) is one of the major challenges in cancer treatment (1), which occurs in a short period of time during/after treatment, and may result in cross resistance to many other structurally and mechanically different chemotherapeutics (2). MDR may be due to different mechanisms, including (1) ATP-binding cassette (ABC) transporters that pump out chemotherapeutics (3), (2) the mutation of oncogenes that become resistant to former treatments $(4,5),(3)$ an evolving adaptation of cancer cells to the microenvironment $(6,7),(4)$ survived cancer stem cells (CSCs) that escape from conventional therapies $(8,9)$, and (5) activated cell growth factors as well as cell defense systems, etc.

As membrane-bound proteins, $\mathrm{ABC}$ transporters refer to 49 transporter proteins that are classified into seven subfamilies, ABCA to ABCG, that locate in the cell membrane and have diverse functions (10). ABC transporters have two nucleotide-binding domains (NBDs) which bind and hydrolyze ATP, and two trans-membrane binding domains (TMDs) which carry their substrates out of the cell $(11,12)$. By using ATP, ABC transporters work to transport their substrates across the cell membrane, and the substrates include building blocks/nutrition such as amino acids, sugars, lipids, vitamins, peptides, and certain proteins etc. Importantly, they can protect cells against xenobiotics, including some anti-cancer drugs (13). Higher expressions of these transporters, such as ABCB1 (also known as P-glycoprotein, P-gp), ABCG2 (also known as breast cancer resistant protein, 
$\mathrm{BCRP}$ ), and ABCC1 (also known as multidrug resistanceassociated protein 1, MRP1), have closely participated in MDR as confirmed by studies from both the laboratory and the clinic $(14,15)$. The overexpression of $\mathrm{ABC}$ transporters may lead to the resistance of conventional chemotherapeutics, such as doxorubicin (Dox), paclitaxel, colchicine, etc., radiotherapy, and targeted therapies, such as imatinib (14).

Cancer cells may also adapt to the changed microenvironment, e.g., the increased oxidative stress, leading to MDR. Oxidative stress is defined as the phenomenon of imbalance between the production of reactive oxygen species (ROS) and antioxidant defenses, which plays a key role in the initialization of many diseases for their impacts on tissue damage (16). Oxidative stress also contributes to tumor development and responses to anticancer therapies (17). Generally, certain level of ROS may benefit cancer cell proliferation and DNA mutations, while high level ROS may be a lethal factor that finally induces cell death (18). Research has shown that ROS levels are higher in cancer cells and in resistant cancer cells due to chemotherapy or radiotherapy $(17,19)$. Accordingly, the corresponding antioxidant pathways that eliminate ROS are up-regulated during tumor initiation and progression, rendering them more vulnerable to further oxidative stress assaults $(18,20)$. Therefore, targeting oxidative stress is a promising strategy to overcome MDR in cancer.

Cancer cells that grow rapidly need more oxygen supply for their energy supply and signal transmission $(21,22)$. Tissue hypoxia occurs due to an inadequate amount of oxygen delivery or due to cancer cell metabolism re-programming, rendering cancer cells to adapt to less oxygen by up-regulating several key proteins, including hypoxia-inducible factor- $1 \alpha$ (HIF- $1 \alpha)$, HIF-2 $\alpha$ (23). More importantly, hypoxia can trigger MDR by impacting the efficacy of anticancer drugs (24). Furthermore, hypoxia may also induce the expression of ABCB1 and ABCG2 that pump out intracellular chemotherapeutic agents $(25,26)$, a common MDR mechanism.

Cancer stem cells (CSCs), a subset of cells within the tumor, that possess the potential of self-renewal, differentiation and tumorigenicity, are thought to be the major cause of cancer therapy failure due to their chemo- and radio-resistance $(9,27)$. CSCs are situated in the niche, which are mainly composed of fibroblasts and endothelial, mesenchymal and immune cells, playing pivotal roles in drug resistance (28). Therefore, the elimination of CSCs represents one promising strategy to overcome MDR.

The cell cycle, the mechanism of cell division, is composed by four phases: the G1 phase, during which a cell begins to grow in size to be ready to DNA synthesis; the $\mathrm{S}$ phase (synthesis), during which cell synthesizes DNA; the G2 phase, during which a cell continues to grow to be ready for mitosis; the $M$ phase (mitosis), during which the cell stops growing and divides into two cells $(29,30)$. The cell cycle is driven by cyclindependent kinases (CDKs) which are regulated by cyclins (cyclin A-Y). Studies have shown that certain phases of the cell cycle exhibit resistance to chemotherapeutics $(31,32)$, and cancer cells that over-express CDKs and cyclins demonstrate resistance to conventional chemotherapeutics (33-35).
Autophagy, a self-degradative system in which cells undergo degradation of intracellular components, is important for the energy balance in response to nutrient stress $(36,37)$. During chemotherapy, autophagy works as a prosurvival and resistance mechanism; therefore, the inhibition of autophagy can re-sensitize MDR cells and enhance the cytotoxicity of chemotherapeutic agents (38).

Epithelial mesenchymal transition (EMT), a biologic process that polarized epithelial cells undergoes multiple biochemical changes to achieve mesenchymal cell phenotype including enhanced metastasis, invasiveness, drug resistance (39, 40), which play an important role in the morphogenesis of multicellular organisms (41).

Other key enzymes in cancer cells are also overexpressed to evade the cell death induction caused by chemotherapeutics. Signal transducer and the activator of the transcription (STAT) protein family (STAT 1-6) are intracellular transcription factors that mediate cellular differentiation, proliferation, hematopoiesis, and apoptosis by transmitting signals from the cell surface receptors to the nucleus (42). STAT3 plays a pivotal role in tumor growth and metastasis and it is activated and up-regulated in solid tumors and resistant cancers, suggesting it as a promising target to overcome MDR (43-45).

p53 (also known as TP53) is a classic tumor suppressor gene that induces cell cycle arrest and apoptosis (46). Usually, p53 is down-regulated or mutated in cancer cells, especially in the cancer cells of MDR (47).

Another key player, the nuclear factor kappa-light-chainenhancer of activated B cells (NF- $\mathrm{B})$, composed with five transcription factors, can bind to DNA sequences at promoter regions of responsive genes to regulate cellular processes such as DNA transcription, cytokine production, and cell survival (48). Activated NF- $\mathrm{B}$ not only promotes tumor cell proliferation and apoptosis suppression, but it also induces EMT which facilitates distant metastasis and drug resistance $(49,50)$.

Various MDR reversal agents have been developed and some of them have entered into clinical trials, however, most of them failed due to severely adverse effects or because they suffered resistance in a short time $(51,52)$. Effective novel agents that surmount MDR remain an unmet clinical need.

Natural products are the major resource for new lead compound identification and new drug discoveries, which account for nearly $50 \%$ over the past three decades (53). Of all the versatile chemical structures, flavonoids are one of the most intensively studied. Flavonoids are abundant in plants, foods such as fruits and vegetables, as well as in traditional herbs (5456). Importantly, many flavonoids have been applied in humans for nutrition supply and for certain disease treatment $(57,58)$, indicating their safety properties. Structurally, flavonoids are classified into three categories: flavonoids; iso-flavonoids; neoflavonoids, as shown in Figure 1. Specifically, flavonoids have a backbone of 2-phenyl-1,4-benzopyrone, iso-flavonoids have a backbone of 3-phenyl-1,4-benzopyrone, and neo-flavonoids have a backbone of 4-phenyl-1,2-benzopyrone. To date, $\sim 5,000$ diverse flavonoids have been identified (59).

Flavonoids are usually termed as multi-targeting and multifunctional molecules, as they possess multiple bioactivities, such 


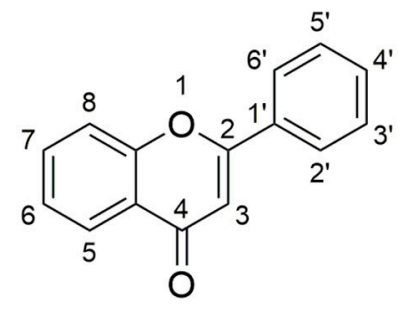

Flavonoids

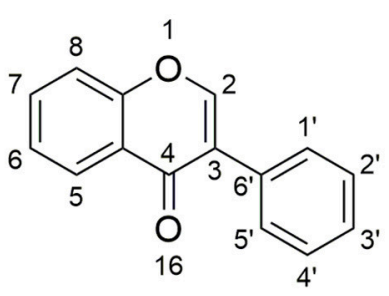

Iso-flavonoids

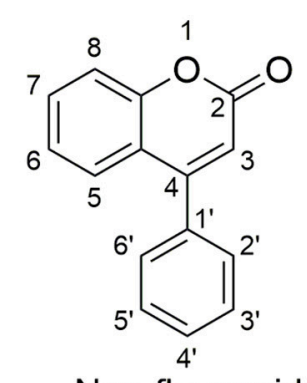

Neo-flavonoids

FIGURE 1 | Structural backbones of flavonoid, iso-flavonoid, neo-flavonoid.

as cardiovascular protective effects (60), nerve system protective effects (61), anti-aging (62), anti-inflammatory (63), anti-cancer (64), so on and so forth. More importantly, flavonoids (as summarized in Figure 2) have been found to kill resistant cancer cells or to re-sensitize conventional anti-cancer drugs to reverse MDR via the mechanisms discussed above, indicating their appealing potential in resistant cancer treatment. Here, we summarize these reports and discuss the analyzing of underlying mechanisms.

\section{MULTI-FUNCTIONAL FLAVONOIDS OVERCOME MDR IN CANCER}

\section{Flavonoids That Regulate ABC Transporters to Overcome MDR}

Many flavonoids, such as Chrysin, Baicalein, Kaempferol, Quercetin, Rutin, Icaritin, and iso-flavonoids, such as Genistein and Biochanin $\mathrm{A}$, have been found to regulate ABCB1, ABCG2, $\mathrm{ABCC} 1$ and other transporters to reverse MDR.

Chrysin, 5,7-dihydroxyflavone, which presents in honey, propolis, and the passion flower Passiflora caerulea (65), exhibits various bioactivities, including anti-cancer effects as it is reported to inhibit aggressive anaplastic thyroid cancer cells (66) and drug resistant triple-negative breast cancer cells (TNBC) (67). Chrysin can inhibit ABCB1 mediated rhodamine 123 (an ABCB1 substrate) efflux on human breast cancer cells MDA-MB-231 (68). Chrysin may also regulate ABCG2 mediated nitrofurantoin transport on ABCG2-overexpressing human MCF-7 breast cancer cells by increasing the area under the curve (AUC) (69). Moreover, Chrysin sensitizes the ABCG2-transfected cells to mitoxantrone (an ABCG2 substrate) via stimulating ATPase (70).

Baicalein, 5,6,7-Trihydroxyflavone, isolated from Scutellaria baicalensis and Scutellaria lateriflora (71), holds potential in treating breast cancer (72), colorectal cancer (73), bladder cancer (74), etc. Baicalein may reverse ABCB1 mediated MDR as shown on $\mathrm{ABCB} 1$ gene transfected Madin-Darby canine kidney II (MDCK II) cells (75). Baicalein induces apoptosis and autophagy and decreases $\mathrm{ABCB} 1$ and anti-apoptotic Bcl-xl expression levels on 5-fluorouracil (5-FU) and Epirubicin resistant hepatocellular carcinoma cells (Bel7402/5-FU). By inhibiting an ABCB1mediated drug efflux, Baicalein $(5 \mathrm{~g} / \mathrm{ml}$ and $10 \mathrm{~g} / \mathrm{ml})$ increases the intra-cellular concentrations of rhodamine 123 and Epirubicin (76). Through this similar mechanism, Baicalein enhances the cytotoxic effects of docetaxel in anaplastic thyroid cancer $8505 \mathrm{c}$ cells (77), and paclitaxel in its resistant MCF-7/Tax cells and in an animal model (78).

Apigenin, 4',5,7-Trihydroxyflavone, isolated from Apium graveolens (79), shows anti-cancer effects to human breast cancer (80), prostate cancer (81), and imatinib-sensitive and resistant chronic myeloid leukemia K562/IMA3 cells (82). One molecular docking study indicates that Apigenin binds to the NDBs of $\mathrm{ABCB} 1$ and $\mathrm{ABCB} 5$ (83). Apigenin inhibits $\mathrm{ABCB} 1$ expression and re-sensitizes docetaxel-resistant prostate cancer DU145 cells to docetaxel (84). Through down-regulating ABCB1, Apigenin $(2,8 \mu \mathrm{M})$ significantly enhances the efficacy of doxorubicin (Dox, an ABCB1 substrates) in its resistant MES-SA/Dx5 cells (85) and breast cancer cells (MCF7/ADR) (86).

Acacetin, O-methylated Apigenin, found in Robinia pseudoacacia, Turnera diffusa, and Betula pendula (87), exhibits anti-cancer effects in prostate cancer cells (88) and hepatocellular carcinoma (89) etc. Acacetin inhibits the activities and functions of both ABCB1 $(90,91)$ and ABCG2 (92). Through downregulating $\mathrm{ABCB} 1$ in non-small cell lung cancer (NSCLC) cells, Acacetin decreases efflux of Dox by $59 \%$ and further increases accumulation of Dox inside the cells up to 55\%, leading to synergistic cytotoxic effects (91). As an ABCG2 inhibitor, Acacetin potentiates the cytotoxicity of SN-38 and mitoxantrone (both are ABCG2 substrates) in ABCG2-transfected K562 (K562/BCRP) cells (92).

Wogonin, 5,7-dihydroxy-8-methoxyflavone, isolated from Scutellaria baicalensis (93), exhibits multiple anti-cancer effects to gastric cancer cells, lung cancer cells and glioma cancer cells (94-96). Wogonin appears to be an inhibitor of ABCB1 (97), and it suppresses the function of $\mathrm{ABCB} 1$ and increases the cellular content of etoposide in HL-60 cells (98). In Dox-resistant human myelogenous leukemia K562/A02 cells, Wogonin re-sensitizes Dox by inhibiting functional activity and expression of ABCB1 at both protein and mRNA levels (99).

Kaempferol, 3,4',5,7-tetrahydroxyflavone, a secondary metabolite found in many plants, plant-derived foods, and traditional medicines (100), possesses inhibitory activities to gastric cancer cells, lung cancer cells $(101,102)$, and tyrosine kinase inhibitor (TKI)-resistant lung cancer cell line H1993 


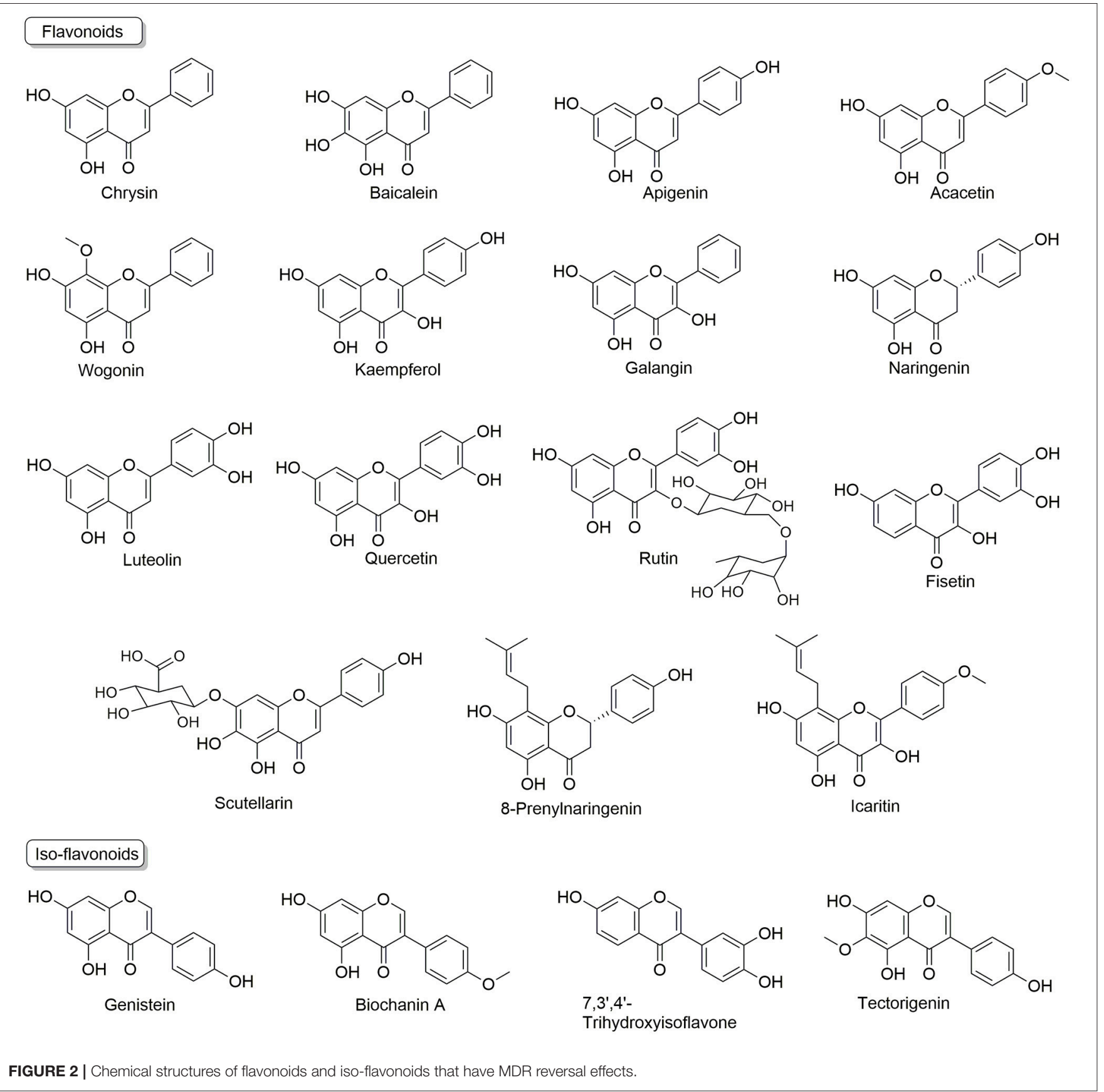

(103). Kaempferol can inhibit the efflux of ABCB1 via stimulating ATPase activity $(104,105)$. It is also an ABCG2 substrate and it suppresses ABCG2 up-regulation (106), indicating its potential as a reversal agent. Indeed, Kaempferol $(20 \mu \mathrm{M})$ shows a synergistic efficacy with cisplatin in surmounting ovarian cancer OVCAR-3 cells, and the combination inhibits the mRNA levels of ABCC6 and cMyc (107).

Naringenin, $4^{\prime}, 5,7$-Trihydroxyflavanone, present in many fruits, and herbs (108), exhibits inhibitory effects to prostate cancer cells and glioblastoma cells $(109,110)$. Naringenin may inhibit the efflux of ABCB1 (111) via interactions with the hydrophobic pocket of the transporter as confirmed by a docking study (111). Through this mechanism, Naringenin significantly enhances the cytotoxicity of daunomycin to resistant human breast cancer cell lines MCF-7/ADR cells (112).

Quercetin, found in many fruits, vegetables, leaves, and grains, has been used as a nutrition supply for many years (113). Quercetin has been reported to kill many types of cancer cells, including human breast cancer MCF-7 cells (114), NSCLC A549 cells (115), ovarian cancer cells (116), etc. Quercetin is able to block the function and expression of ABCB1 and $\operatorname{ABCC} 1, \operatorname{ABCC} 2(112,117,118)$. As tested in 5-FU resistant 
human hepatocellular carcinoma BEL/5-FU cells, Quercetin inhibits the functions and down-regulates the expressions of $A B C B 1, A B C C 1, A B C C 2$ (118). Quercetin is found to inhibit the pumping effects of these three transporters, evidenced by more intracellular accumulation of rhodamine-123 and Dox (118). On ABCB1 over-expressing and Dox resistant human breast cancer MCF-7/dox cells, Quercetin significantly enhances the antitumor activity of Dox, paclitaxel, and vincristine. The combined treatment of Dox, paclitaxel, and vincristine with Quercetin significantly down-regulates ABCB1 expression and eliminates breast cancer stem cells (119). Further studies also confirms the reversal effects of Quercetin $(0.7$ and $25-100 \mu \mathrm{M}$, respectively) in MCF-7/dox cells (120) and in gene-encoded ABCB1 overexpressing oral cancer KB/VCR cells (121).

Other flavonoids that regulate $\mathrm{ABC}$ transporters include Rutin, a quercetin glycoside that inhibits the pumping effects of ABCB1 and ABCG2 $(117,122)$, Fisetin, found in many that has been found to possess sensitizing effects to conventional chemotherapeutics cabazitaxel (123) and paclitaxel or arsenic trioxide in NSCLC (124), 3,3' $4^{\prime}, 7$-Tetrahydroxyflavone, found in many fruits and vegetables (125), inhibits the function of ABCB1 (85), as well as 8-Prenylnaringenin (126), a prenylflavonoid phytoestrogen found in hops (Humulus lupulus) and beer (127), and a clinical drug candidate Icaritin (under clinical trials in China for treatment of hepatocellular carcinoma), both of which inhibit the efflux of ABCB1 and ABCC1 $(128,129)$.

In addition, there are two iso-flavonoids that regulate $\mathrm{ABC}$ transporters. Genistein, 4',5,7-Trihydroxyisoflavone, found in a number of plants including lupin, fava beans, soybeans, is an angiogenesis inhibitor that exhibits anti-cancer activities (130). Genistein is also reported to be an inhibitor of ABCB1, ABCG2 (131, 132). As tested in ABCG2-transduced MDCK-II cells, Genistein can inhibit the transport of Danofloxacin, a substrate of ABCG2 (133). Other further applications to reverse MDR mediated by $\mathrm{ABC}$ transporters remain to be explored.

Biochanin A, 5,7-Dihydroxy-4'-methoxyisoflavone, found in soy, exerts certain anti-cancer effects $(134,135)$. Biochanin A is found to be an ABCG2 inhibitor, as it increases the accumulation and cytotoxicity of mitoxantrone in mitoxantrone resistant MCF7 MX100 cells which over-express ABCG2 (136).

\section{Flavonoids That Regulate Oxidative Stress to Overcome MDR}

Many flavonoids are reported to either increase ROS or inhibit the antioxidant enzymes, exhibiting MDR reversing potential.

Baicalein significantly induces ROS production on tumor necrosis factor-related apoptosis-inducing ligand (TRAIL) resistant prostate cancer PC3 cells, leading to TRAIL resensitization. The ROS scavenger catalase prevents TRAIL sensitization, indicting it a ROS mediated mechanism (137).

$\mathrm{Nrf2}$, a transcription factor, works with kelch-like ECHassociated protein 1 (Keap1) and the antioxidant response element (ARE) as a cytoprotective response to endogenous and exogenous stresses caused by ROS via the up-regulation of antioxidant proteins (138). A higher level of Nrf2 and its target proteins contributes in Dox resistance in BEL-7402/ADM cells
(139). Chrysin suppresses Nrf2 at both protein and mRNA levels to BEL-7402/ADM cells, sensitizing the cells to Dox. Moreover, Chrysin also increases the intracellular concentration of Dox (139). Glutathione (GSH) is a peptide that significantly reduces the damage caused by toxic xenobiotics and ROS (140, 141). By depleting 50 to $70 \%$ of intracellular GSH within $24 \mathrm{~h}$, Chrysin potentiates the cytotoxicity of curcumin (a natural occurring compound that kills cancer cells) to PC-3 cells and human leukemia cell line HL-60 cells (142). This effect is also found in non-small cell epithelial cancer cell lines A549, H157, H460, and H1975 (143). Co-treating with Chrysin (5-30 $\mu \mathrm{M})$ significantly enhances the sensitivity of the cells to Dox as compared to Dox alone. Mechanistically, Chrysin may facilitate GSH efflux as demonstrated in Brechbuhl's study (143).

Wogonin robustly induces ROS accumulation in A549 cells and further sensitize A549 cells to TRAIL-induced apoptosis in vitro and in vivo, which can be reversed by ROS scavenger butylated hydroxyanisole (BHA) and N-acetyl-L-cysteine (NAC) (144). Moreover, Wogonin suppresses nuclear translocation of Nrf2 by NF- $\kappa$ B inactivation and induces more intracellular ROS as shown in K562/A02 cells and in HepG2 cells (145, 146), enhancing the effects of Dox in K562/A02 cells. Apigenin also lowers the GSH level, which then increases ROS levels, resulting in cell death of ABCC1 over-expressing H69AR-drug selected and HeLa/ABCC1-transfectant cells (147). Through similar mechanisms, Wogonin may enhance the efficacy of (1) cisplatin in cisplatin resistant HNC cells (149), (2) Dox in its resistant human myelogenous leukemia K562/A02 cells (99), and MCF-7/DOX cells (148).

Luteolin, $3^{\prime}, 4^{\prime}, 5,7$-Tetrahydroxyflavone, which is abundant in leaves and aromatic flowering plants, possesses inhibitory effects to pancreatic cancer cells (149), colorectal adenocarcinoma LoVo cells and in drug-resistant LoVo/Dx cells (150), etc. Luteolin is also able to inhibit Nrf2 markedly and enhance the cytotoxicity of cisplatin in cholangiocarcinoma KKU-100cells (151). By inhibiting Nrf2 (152), luteolin may enhance the efficacy of (1) oxaliplatin in oxaliplatin-resistant colorectal cancer cell lines HCT116-OX and SW620-OX cells (153), (2) bleomycin, Dox in A549 cells (154), and Dox in MDA-MB 231 cells (155).

Other flavonoid that modulate ROS includes Galangin, purified from the Alpinia galangal root, exhibits collateral sensitivity (156), a phenomenon where one compound shows better inhibitory effects to resistant cancer cells over sensitive cells (157).

The iso-flavonoid Genistein and $7, \mathbf{3}^{\prime}, \mathbf{4}^{\prime}$ trihydroxyisoflavone, one of the major metabolites of daidzein found in fruits, nuts, and soy-based food (158), also exhibits bioactivity to Nrf2 and ROS. Genistein down-regulates the level of methylation in the Keap1 promoter region, which inhibits the transcription of $\mathrm{Nrf} 2$ to the nucleus, resulting in the suppression of Nrf2-dependent antioxidant enzymes and up-regulation of ROS in A549 cells (159). Through this mechanism, Genistein significantly increases cell apoptosis in A549 cells when combined with radiation (159). Through the induction of ROS and by down-regulating $\mathrm{ABC}$ transporters

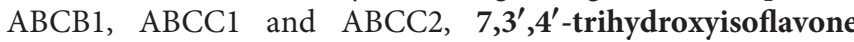
$(25 \mu \mathrm{M})$, significantly increases the intracellular accumulation 
of epirubicin and attenuates epirubicin resistant in HeLa cells (160).

\section{Flavonoids That Regulate Hypoxia to Overcome MDR}

Many flavonoids are found to regulate hypoxia to reverse MDR.

Baicalein suppresses the HIF-1 $\alpha$ expression in 5-FU resistant gastric cancer AGS cells ny inhibiting the hypoxia-induced Akt phosphorylation, which finally leads to re-sensitizing 5-FU (161).

Wogonin decreases the expression of HIF- $1 \alpha$ in human colon cancer cell lines HCT116 by inhibiting the PI3K/Akt signaling pathway. Through this mechanism, Wogonin enhances the cytotoxicity of Dox, cisplatin, paclitaxel to HCT116 cells (162).

Quercetin is another flavonoid that regulates HIF- $1 \alpha$, which consequently re-sensitizes Dox to Dox resistant breast cancer MCF-7/dox cells (120), and 4T1 cells (163), cisplatin and etoposide to HCT116 cancer cells (164).

\section{Flavonoids That Regulate CSCs to Overcome MDR}

Many flavonoids have been shown to suppress the growth of CSCs.

Baicalein may selectively re-sensitize $\mathrm{CD}_{133^{+}}$tumor initiating CSCs (isolated from human liver tumors which exhibit drug resistance properties) to certain chemotherapeutics (36). Baicalein inhibits the SAR1B GTPase which is necessary for autophagy, a way cancer cells apply to avoid cytotoxic effects induced by chemotherapeutics (36). Furthermore, Baicalein works synergistically with the mTORC1 inhibitor in a patientderived xenograft model of hepatocellular carcinoma via elimination of CSCs (165).

On human $\mathrm{CD} 44^{+}$prostate CSCs (isolated from human PC3 cells) which confer MDR, Apigenin is able to significantly enhance cisplatin's efficacy by down-regulating the mRNA expression of anti-apoptotic $\mathrm{Bcl}-2$, sharpin and surviving, and up-regulating pro-apoptotic caspase-8 and p53 (166). On another two CSCs cells, glioblastoma multiforme U87MG and U373MG cells, Apigenin significantly suppresses the cell growth, clonogenicity, and invasiveness, three key factors that represent the self-renewal property of CSCs. Mechanically, Apigenin blocks the phosphorylation of c-Met and its down-stream targets, such as the transducer and activator of transcription 3 (STAT3), Akt and protein kinase mitogen-activated protein kinase (MAPK) (167).

Wogonin exhibits anti-CSCs effects, as shown on CD133 human osteosarcoma CSCs (168). Wogonin induces apoptosis, inhibiting the mobility by down-regulating the expression of metallopeptidase-9, leading to a halt in its renewal ability (168).

Other flavonoids that regulate CSCs are Luteonin and Quercetin. Luteonin is able to eliminate the CD44+/CD49f+ CSCs isolated from TNBC via ribosomal S6 kinase inhibition (169). Quercetin may suppress the self-renewal property of pancreatic cancer stem-like cells which is gemcitabine resistant via targeting $\beta$-catenin, restoring the sensitivity of gemcitabine in vitro and in vivo (170). Quercetin also inhibits the breast CSCs (171), colorectal CSCs and restores the sensitivity of Dox (172).

\section{Flavonoids That Regulate the Cell Cycle to Overcome MDR}

Some flavonoids have been shown to regulate the cell cycle to overcome MDR.

The cyclin E2 mRNA and protein expression was higher in tamoxifen resistant MCF-7 cells compared with sensitive cells. Luteolin specifically inhibits the Cyclin E2 protein expression in resistant cells and exhibits a synergistic effect with tamoxifen (173).

By down-regulating cyclin D1, Quercetin significantly enhances the efficacy of Dox in TNBC cells (174), and cisplatin in ovarian carcinoma SKOV3 cells and osteosarcoma U2OS cells (175).

Scutellarin, an active flavone extracted from Erigeron breviscapus Hand-Mazz, down-regulates Cdc2, cyclin B1, two cell cycle related proteins, and induces G2/M arrest and apoptosis to PC3 cells, and restores the sensitivity of cisplatin (176).

\section{Flavonoids That Regulate Autophagy to Overcome MDR}

In Dox resistant BEL-7402/ADM cells, Apigenin significantly enhances the sensitivity of Dox, induces miR-520b expression and inhibits autophagy-related protein 7 (ATG7)-dependent autophagy in vitro and in hepatocellar carcinoma xenografts model (177).

Treatment of ovarian cancer cells with cisplatin may elevate poly [ADP-ribose] polymerase 1 (PARP-1), which is important for cell survival by regulating autophagy. Leteolin can inhibit PARP-1 at both the mRNA and protein level, and suppress autophagy, restoring the sensitivity to cisplatin (178).

Another flavonoid Icaritin can inhibit epirubicin-induced autophagy which may cause epirubicin resistance, and acts synergistically with epirubicin to suppress the proliferation of BT5637 and T24 cells (179).

\section{Flavonoids That Regulate EMT to Overcome MDR}

As shown in pemetrexed-resistant NSCLC A549-R, H358$\mathrm{R}, \mathrm{H} 460-\mathrm{R}$ cells, EMT pathway promotes the MDR profile. Kaempferol is able to inhibit EMT signaling, rendering the resistant cancer cells susceptible to pemetrexed (180).

Another study indicates that EMT contributes in paclitaxelresistance in ovarian cancer X10 and X22 cells. Luteolin at noncytotoxic dose can reverse EMT, and re-sensitize the two cells to paclitaxel (181).

\section{Flavonoids That Regulate Critical Enzymes to Overcome MDR \\ STAT3}

Chrysin selectively decreases the STAT3 phosphorylation to A549 cells, and re-sensitizes A549 cells to TRAIL (182).

On cisplatin-resistant lung cancer A549/DDP cells, combination of Galangin and cisplatin suppresses the cell 
proliferation through inhibiting p-STAT3 and anti-apoptotic Bcl2 and increasing pro-apoptotic Bax and Bid. This combination also exhibits potency in mice xenograft models (183).

Similar results are also found by pretreatment of Quercetin which significantly enhances the cytotoxicity of cisplatin in an ovarian cancer cell line by suppressing STAT3 phosphorylation and Bcl-2. In a xenograft mouse model of ovarian cancer, Quercetin enhances the antitumor effect of cisplatin (184).

\section{p53}

Li et al. reported that a combination of Chrysin and cisplatin increases $\mathrm{p} 53$ phosphorylation and accumulation by activating ERK1/2 in HepG2 cells, leading to significant apoptosis, evidenced by the over-expression of pro-apoptotic proteins Bax, death receptor 5 and the inhibition of the anti-apoptotic protein Bcl-2 (185).

Apigenin is reported to elevate p53 and up-regulate certain pro-apoptotic proteins, which may increase cisplatin-induced DNA damage and apoptosis of A549 and H1299 cells (186).

Quercetin may potentiate 5-FU in 5-FU resistant HCT15 cells (which harbor a p53 mutation) by increasing p53 expression and activating the apoptotic mitochondrial pathway (187).

Through activating the extracellular signal-regulated kinases (ERK)-mediated p53 pathway, Scutellarin is capable of sensitizing A549/DDP cells to cisplatin in vitro and in vivo (188).

\section{NF-кB}

By decreasing the activity and of NF- $\kappa \mathrm{B}$, Fisetin increases the expression of death receptor TRAIL-R1, strengthening the apoptosis induction effects of TRAIL to TRAIL-resistant androgen-dependent LNCaP cells (50).

Genistein is able to suppress NF- $\kappa \mathrm{B}$, potentiate cisplatin, docetaxel, Dox or gemcitabine in various cancer cells including prostate, breast, lung, pancreatic and ovarian cancer cells (189-191). Similarly, genistein also enhances oxaliplatin in gemcitabine-resistant pancreatic cancer cells (192), gemcitabine in osteosarcoma cells, cisplatin in medulloblastoma cells (193), arabinoside in acute myeloid leukemia cells (194), and arsenic trioxide in human hepatocellular carcinoma cells in vitro and in vivo (195), suggesting it a promising reversal agent.

The activation of NF- $\mathrm{B}$ contributes to TRAIL resistance of prostate cancer LNCaP and DU145 cells. Biochanin A significantly augments the cytotoxicity of TRAIL in these two cell lines, and it sensitizes the TRAIL-resistant LNCaP cells through NF- $\kappa$ B inhibition, leading to an up-regulated death receptor TRAIL-R2, and the disrupted mitochondrial membrane potential (196).

Tectorigenin, isolated from the flowers of Pueraria thunbergiana (197), exhibits re-sensitizing effects on paclitaxelresistant ovarian cancer cells MPSC1(TR), A2780(TR) and SKOV3(TR) (198). Tectorigenin inhibits NF- $\kappa B$ nuclear translocation and its target genes, such as FLIP, XIAP, Bcl-2, $\mathrm{Bcl}-\mathrm{xL}$, and COX-2, all of which are known to be associated with MDR. Consequently, Tectorigenin enhances the inhibitory effect of paclitaxel in these three paclitaxel-resistant ovarian cancer cells (198).

\section{Flavonoids That Regulate Other Key Enzymes Regulated to Overcome MDR}

It should be noted that apart from the aforementioned three key players in MDR, flavonoids also regulate other enzymes, e.g., Fisetin and Genistein regulate Akt to suppress Irinotecan and Oxaliplatin resistant CPT11-LoVo cells in vitro and in vivo (199), and enhance the cytotoxicity of cisplatin in A549 cells (200), respectively. Fisetin decreases the phosphorylated

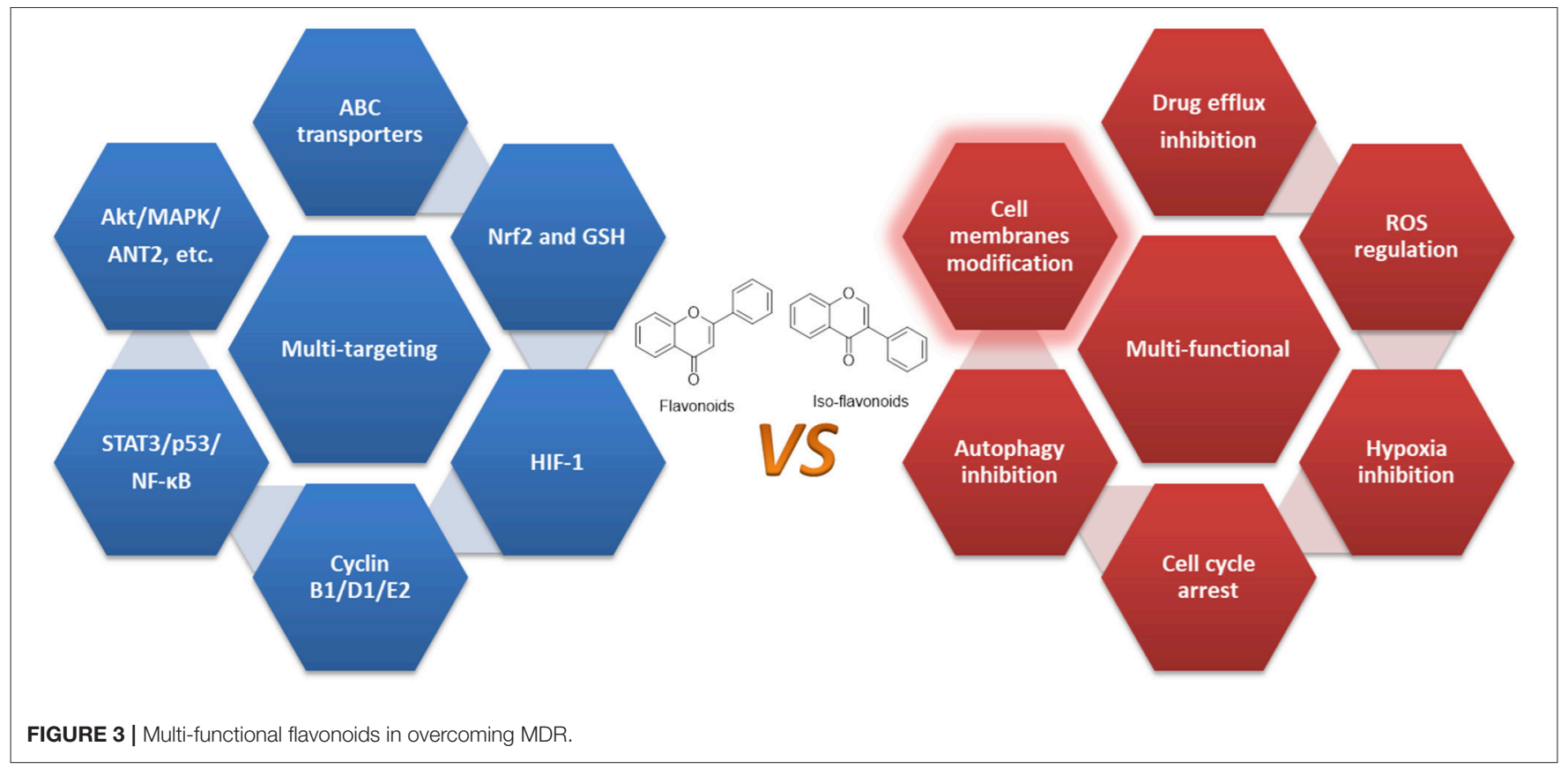


MAPK to increase the sensitivity of cisplatin-resistant A549CR cells to cisplatin (201) and erlotinib-resistant lung cancer cells to erlotinib (202). Apigenin inhibits adenine nucleotide translocase-2 (ANT2) to enhance the efficacy of TRAIL to prostate cancer DU145 and LNCaP cells (203). Luteolin inhibits vaccinia-related kinase 1 (VRK1) to enhance the efficacy of cisplatin in esophageal squamous cell carcinoma (204). Quercetin suppresses the proliferation of tamoxifen resistant breast cancer TAMR-MCF-7 cells by inhibiting the expression of Pin1, vascular endothelial growth factor (VEGF), HIF as well as activator protein-1 (AP-1) (205). Quercetin also resensitizes enzalutamide to enzalutamide-resistant prostate cancer cells to in vitro and in vivo by inhibiting Androgen receptor splice variant 7 (AR-V7) (206). Genistein abolishes the increased cyclooxygenase-2 (COX-2) to 5-FU resistant HT-29 colon cancer cells (207) and induces the cleavage of Bid to TRAIL resistant

TABLE 1 | Summary of the flavonoids with MDR reversal effects and their application.

\begin{tabular}{|c|c|c|c|}
\hline Compound name & Functions & Application & References \\
\hline Chrysin & $\begin{array}{l}\text { ABC transporters regulation } \\
\text { ROS induction } \\
\text { STAT3 inhibition } \\
\text { p53 inhibition }\end{array}$ & $\begin{array}{l}\text { Sensitizing mitoxantrone } \\
\text { Sensitizing Dox, curcumin } \\
\text { Sensitizing TRAlL } \\
\text { Sensitizing cisplatin }\end{array}$ & $\begin{array}{c}(70) \\
(139,142) \\
(182) \\
(185)\end{array}$ \\
\hline Baicalein & $\begin{array}{l}\text { ABC transporters regulation } \\
\text { ROS induction } \\
\text { Hypoxia suppression } \\
\text { CSCs inhibition }\end{array}$ & $\begin{array}{l}\text { Sensitizing docetaxel, paclitaxel } \\
\text { Sensitizing TRAIL } \\
\text { Sensitizing 5-FU } \\
\text { Sensitizing mTORC1 inhibitor }\end{array}$ & $\begin{array}{l}(77,78) \\
(137) \\
(161) \\
(165)\end{array}$ \\
\hline Apigenin & $\begin{array}{l}\text { ABC transporters regulation } \\
\text { CSCs inhibition } \\
\text { Autophagy inhibition } \\
\text { p53 inhibition }\end{array}$ & $\begin{array}{l}\text { Sensitizing docetaxel, doxorubicin } \\
\text { Killing resistant CSCs } \\
\text { Sensitizing Dox } \\
\text { Sensitizing cisplatin }\end{array}$ & $\begin{array}{c}(84-86) \\
(166,167) \\
(177) \\
(186)\end{array}$ \\
\hline Acacetin & ABC transporters regulation & Sensitizing Dox, SN-38 & $(91,92)$ \\
\hline Wogonin & $\begin{array}{l}\text { ABC transporters regulation } \\
\text { ROS induction } \\
\text { Hypoxia suppression } \\
\text { CSCs inhibition }\end{array}$ & $\begin{array}{l}\text { Sensitizing Dox } \\
\text { Sensitizing Dox, cisplatin } \\
\text { Sensitizing Dox, cisplatin, paclitaxel } \\
\text { Killing resistant CSCs }\end{array}$ & $\begin{array}{c}(99) \\
(147,233) \\
(162) \\
(168)\end{array}$ \\
\hline Kaempferol & $\begin{array}{l}\text { ABC transporters regulation } \\
\text { EMT suppression }\end{array}$ & $\begin{array}{l}\text { Sensitizing cisplatin } \\
\text { Sensitizing pemetrexed }\end{array}$ & $\begin{array}{l}(107) \\
(180)\end{array}$ \\
\hline Galangin & $\begin{array}{l}\text { ROS induction } \\
\text { STAT3 inhibition }\end{array}$ & $\begin{array}{l}\text { Collateral sensitivity } \\
\text { Sensitizing cisplatin }\end{array}$ & $\begin{array}{l}(157) \\
(183)\end{array}$ \\
\hline Naringenin & ABC transporters regulation & Sensitizing daunomycin & $(112)$ \\
\hline Luteolin & $\begin{array}{l}\text { ROS induction } \\
\text { CSCs inhibition } \\
\text { Cell cycle regulation } \\
\text { Autophagy inhibition } \\
\text { EMT suppression }\end{array}$ & $\begin{array}{l}\text { Sensitizing oxaliplatin, Dox } \\
\text { Killing resistant CSCs } \\
\text { Sensitizing tamoxifen } \\
\text { Sensitizing cisplatin } \\
\text { Sensitizing paclitaxel }\end{array}$ & $\begin{array}{c}(151,153-155) \\
(169) \\
(173) \\
(178) \\
(181)\end{array}$ \\
\hline Quercetin & $\begin{array}{l}\text { ABC transporters regulation } \\
\text { Hypoxia suppression } \\
\text { CSCs inhibition } \\
\text { Cell cycle regulation } \\
\text { p53 inhibition }\end{array}$ & $\begin{array}{l}\text { Sensitizing Dox, paclitaxel } \\
\text { Sensitizing Dox, cisplatin, etoposide } \\
\text { Sensitizing gemcitabine, Dox } \\
\text { Sensitizing Dox, ciaplatin } \\
\text { Sensitizing 5-FU }\end{array}$ & $\begin{array}{c}(119-122) \\
(120,163,164) \\
(170,172) \\
(175) \\
(187)\end{array}$ \\
\hline Rutin & ABC transporters regulation & Sensitizing paclitaxel & $(117)$ \\
\hline Fisetin & $\begin{array}{l}\text { ABC transporters regulation } \\
N F-\kappa B \text { inhibition }\end{array}$ & $\begin{array}{l}\text { Sensitizing cabazitaxel, paclitaxel } \\
\text { Sensitizing TRAIL }\end{array}$ & $\begin{array}{c}(123,124) \\
(50)\end{array}$ \\
\hline Scutellarin & $\begin{array}{l}\text { Cell cycle regulation } \\
\text { p53 inhibition }\end{array}$ & $\begin{array}{l}\text { Sensitizing cisplatin } \\
\text { Sensitizing cisplatin }\end{array}$ & $\begin{array}{l}(176) \\
(188)\end{array}$ \\
\hline Icaritin & $\begin{array}{l}\text { ABC transporters regulation } \\
\text { Autophagy inhibition }\end{array}$ & $\begin{array}{l}\text { Sensitizing Dox } \\
\text { Sensitizing epirubicin }\end{array}$ & $\begin{array}{l}(128) \\
(179)\end{array}$ \\
\hline Genistein & $\begin{array}{l}\text { ABC transporters regulation } \\
\text { ROS induction } \\
\text { NF- } \kappa \text { B inhibition }\end{array}$ & $\begin{array}{l}\text { To be explored } \\
\text { Sensitizing radiation } \\
\text { Sensitizing cisplatin, Dox, gemcitabine }\end{array}$ & $\begin{array}{c}(131-133) \\
(159) \\
(189-191)\end{array}$ \\
\hline Biochanin A & $\begin{array}{l}\text { ABC transporters regulation } \\
\text { NF-кB inhibition }\end{array}$ & $\begin{array}{l}\text { Sensitizing mitoxantrone } \\
\text { Sensitizing TRAIL }\end{array}$ & $\begin{array}{l}(136) \\
(196)\end{array}$ \\
\hline $7,3^{\prime}, 4^{\prime}$-Trihydroxyisoflavone & ROS induction & Sensitizing epirubicin & $(160)$ \\
\hline Tectorigenin & $N F-\kappa B$ inhibition & Sensitizing paclitaxel & $(198)$ \\
\hline
\end{tabular}


human hepatoma cells (208), exerting its sensitizing effects. Chrysin, Apigenin, Luteolin, Quercetin and Genistein, also regulates the ubiquitin-proteasome pathway to overcome MDR in various chemotherapeutic drugs (209).

Furthermore, Chrysin may inhibit the pro-inflammatory mediators including interleukin-6 (IL-6) and the aldo-keto reductases superfamily (AKR1C1/1C2) expression, re-sensitizing cisplatin and Dox in NSCLC (210).

Apigenin also targets $\mathrm{Axl}$ and Tyro3 receptor tyrosine kinase (211), and impacts mitochondrial membrane potential (212), antagonizes Mcl-1 upregulation (213), or acts as an anti-estrogen and a protein kinase inhibitor (214) to sensitize certain chemotherapeutics.

Kaempferol may also enhance the efficacy of TRAIL in human ovarian cancer cells OVCAR-3 and SKOV-3 cells (215), and U251 and U87 glioma cells (216) via JNK/ERK-CHOP pathway and induction of proteasomal degradation of survivin, respectively.

Wogonin may also regulate AKR1C1/1C2 (210), and tumor necrosis factor- $\alpha$ (217). Wogonin increases Dox sensitivity through the down-regulation of the IGF-1R/AKT signaling pathway in human breast cancer (218), and increases the activity of sorafenib to human hepatocellular carcinoma cells by potentiating apoptosis and inhibiting autophagy (219).

Quercetin may potentiate the effect of fludarabine and ABT-737 against CLL via Mcl-1 inhibition (220), enhance the efficacy of (1) Dox in the Dox resistant prostate cancer (PC)3 cell line (PC3/R) by down-regulating c-met (221) and Dox resistant human leukemic MDR K562/ADR cells by regulating JNK/MAPK (222), (2) TRAIL to pancreatic cancer cells through JNK-mediated cFLIP turnover (223), (3) tamoxifen in tamoxifenresistant breast cancer cell line (MCF-7Ca/TAM-R) by upregulating $\mathrm{ER} \alpha$ and down-regulating Her-2 (224), etc.

\section{DISCUSSION AND FUTURE PERSPECTIVE}

An increasing body of studies have suggested that through single or combinational administration, flavonoids, and isoflavonoids may work as sensitizing agents. While the major issue of mechanism study of flavonoids is the lack of specific targets and their acting mechanisms in surmounting, resistant cancer cells are still not understood properly (55). Currently, studies like those discussed above indicate that these flavonoids exert their anticancer efficacy through multiple mechanisms, and multiple targets, and it's quite clear that certain flavonoids may overcome MDR by regulating various aspects that contribute to MDR. Therefore, they could be characterized as multifunctional natural compounds rather than multi-targeting agents $(54,105,225,226)$.

Flavonoids tend to target lipid bilayers and modify the membrane physicochemical properties to exert their bioactivities (227-230). As demonstrated in Ingólfsson et al.'s study, phytochemicals of different structures (polyphenols including flavonoid) could alter lipid bilayer properties as they localized on the bilayer/solution interface. Through a similar action, they also regulated bio-functions of diverse membrane proteins, suggesting that their actions may be due to the common, membrane bilayer-mediated mechanism (231). Therefore, we conclude that flavonoids do not function as specific regulators of target proteins, but rather as multi-functional agents that negatively regulate the key factors contributing to MDR as well as to other diseases.

To reverse $\mathrm{MDR}$, these flavonoids may regulate many targets. First, the flavonoids may regulate $\mathrm{ABC}$ transporters, such as ABCB1, ABCG2, ABCC1, etc. They not only inhibit the efflux effects of these transporters to many conventional chemotherapeutics, but also inhibit the expressions. Docking studies indicate that they may bind to NBDs of $\mathrm{ABCB} 1$ (83). To date, no $A B C$ transporter regulators have been approved by the FDA because of severe adverse effects. Natural products hold promise to be of lower toxic agents, given that many of the flavonoid regulators already serve as dietary supplements.

Second, as polyphenolic compounds, many flavonoids may work as ROS modulators (18) as they affect the status of ROS level in cancer cells (232). Under different dose, they may work either as ROS scavengers or inducer. To overcome MDR, they preferably work as inducers which induce more ROS production that can reach to the toxic threshold to activate apoptosis (18). Major players in maintaining balanced ROS in cells include Mrf2, $\mathrm{GSH}$, both of which can be inhibited by certain flavonoids to exert their re-sensitizing effects.

Third, they may also regulate HIFs, cell cycle, CSCs, autophagy, and critical enzymes such as STAT3, p53, and NF$\kappa \mathrm{B}$, confirming their multi-functional property as summarized in Figure 3 and Table 1.

Furthermore, certain flavonoids exhibit collateral sensitivity, a phenomenon where one compound shows selectivity to kill resistant cancer cells over sensitive cells (157), such as Galangin and Chrysin (156), apigenin dimer (234), and another flavonoid desmosdumotin B (235), making the flavonoids more appealing agents in treating resistant cancers.

In addition, some of these flavonoids are now under clinical trials to treat certain cancers, such as Apigenin (NCT03139227), Quercetin (NCT03476330, NCT02989129, NCT01912820, NCT01538316), Icaritin (NCT01278810, NCT01972672, NCT02496949). Further positive results will surely entice more researchers to develop them as drug candidates, e.g., MDR reversal agents.

One issue in this research is that most studies are conducted in vitro, so further in vivo studies are warranted. Given that many of the flavonoids are used as ingredients in dietary supplements, their anticancer/sensitizing efficacy could be more readily determined in humans (236-238). The natural products in flavonoids represent novel treatment strategies to overcome MDR in cancer, and structural modifications of these compounds should be of interest for medicinal chemists. Indeed, many flavonoids derivatives have been developed to suppress resistant cancer cells, such as Chrysin acyl derivatives against drugresistant human cancer cells (MES-SA/DX5, LoVo/DX) (239), nitro Genistein derivatives modified by nitro groups against cisplatin-resistant human ovarian cancer A2780 cells (240), 
Quercetin-glutamic acid conjugate (241), and apigenin-based flavonoid dimers (242) against P-gp overexpressing cancer cells, selenium-containing Chrysin and Quercetin derivatives against cisplatin resistant cancer cells (243), Quercetin-3-methyl ether against lapatinib-resistant breast cancer cells (244), etc. These studies provide crucial information for new drug discoveries based on flavonoids.

\section{CONCLUSION}

Dietary natural flavonoids possess multiple bioactivities including anti-cancer and chemo-sensitizing effects. Studies show that they inhibit certain $\mathrm{ABC}$ transporters, antioxidant enzyme Nrf2 and its related enzymes and regulate HIFs, CSCs, autophagy, EMT, etc., to exert their sensitizing effects, suggesting that they are multi-functional molecules.

\section{REFERENCES}

1. Saraswathy M, Gong S. Different strategies to overcome multidrug resistance in cancer. Biotechnol Adv. (2013) 31:1397407. doi: 10.1016/j.biotechadv.2013.06.004

2. Szakacs G, Paterson JK, Ludwig JA, Booth-Genthe C, Gottesman MM. Targeting multidrug resistance in cancer. Nat Rev Drug Discov. (2006) 5:219-34. doi: 10.1038/nrd1984

3. Li W, Zhang H, Assaraf YG, Zhao K, Xu X, Xie J, et al. Overcoming ABC transporter-mediated multidrug resistance: molecular mechanisms and novel therapeutic drug strategies. Drug Resist Updat. (2016) 27:1429. doi: 10.1016/j.drup.2016.05.001

4. Xue M, Cheng J, Zhao J, Zhang S, Jian J, Qiao Y, et al. Outcomes of 219 chronic myeloid leukaemia patients with additional chromosomal abnormalities and/or tyrosine kinase domain mutations. Int J Lab Hematol. (2019) 41:94-101. doi: 10.1111/ijlh.12928

5. Tiribelli M, Latagliata R, Luciano L, Castagnetti F, Gozzini A, Cambrin GR, et al. Impact of BCR-ABL mutations on response to dasatinib after imatinib failure in elderly patients with chronic-phase chronic myeloid leukemia. Ann Hematol. (2013) 92:179-83. doi: 10.1007/s00277-012-1591-2

6. Taylor S, Spugnini EP, Assaraf YG, Azzarito T, Rauch C, Fais S. Microenvironment acidity as a major determinant of tumor chemoresistance: proton pump inhibitors (PPIs) as a novel therapeutic approach. Drug Resist Updat. (2015) 23:69-78. doi: 10.1016/j.drup.2015.08.004

7. Yeldag G, Rice A, Del RHA. Chemoresistance and the self-maintaining tumor microenvironment. Cancers. (2018) 10:E471. doi: 10.3390/cancers10120471

8. Prieto-Vila M, Takahashi RU, Usuba W, Kohama I, Ochiya T. Drug Resistance driven by cancer stem cells and their niche. Int J Mol Sci. (2017) 18:E2574. doi: 10.3390/ijms18122574

9. Koren E, Fuchs Y. The bad seed: cancer stem cells in tumor development and resistance. Drug Resist Updat. (2016) 28:1-12. doi: 10.1016/j.drup.2016.06.006

10. Vasiliou V, Vasiliou K, Nebert DW. Human ATP-binding cassette (ABC) transporter family. Hum Genom. (2009) 3:28190. doi: 10.1186/1479-7364-3-3-281

11. Beis K. Structural basis for the mechanism of ABC transporters. Biochem Soc Trans. (2015) 43:889-93. doi: 10.1042/BST20150047

12. Locher KP. Review. Structure and mechanism of ATP-binding cassette transporters. Philos Trans R Soc Lond B Biol Sci. (2009) 364:23945. doi: $10.1098 /$ rstb.2008.0125

13. Fletcher JI, Williams RT, Henderson MJ, Norris MD, Haber M. ABC transporters as mediators of drug resistance and contributors to cancer cell biology. Drug Resist Updat. (2016) 26:1-9. doi: 10.1016/j.drup. 2016.03 .001

\section{AUTHOR CONTRIBUTIONS}

QY, FH, and R-WJ conceived the topic. QY, KL, QS, QL, JH, FH, and R-WJ wrote the paper.

\section{FUNDING}

This research was funded by the Hainan Provincial Natural Science Foundation of China (Grant number: 817307).

\section{ACKNOWLEDGMENTS}

The authors would like to thank everybody involved in this review, especially Chunxin Huang, Lixin Deng, and all other colleagues for their helpful discussions and input.

14. Kathawala RJ, Gupta P, Ashby CJ, Chen ZS. The modulation of ABC transporter-mediated multidrug resistance in cancer:a review of the past decade. Drug Resist Updat. (2015) 18:1-17. doi: 10.1016/j.drup.2014.11.002

15. Caetano-Pinto P, Jansen J, Assaraf YG, Masereeuw R. The importance of breast cancer resistance protein to the kidneys excretory function and chemotherapeutic resistance. Drug Resist Updat. (2017) 30:1527. doi: 10.1016/j.drup.2017.01.002

16. Betteridge DJ. What is oxidative stress? Metabolism. (2000) 49:38. doi: 10.1016/S0026-0495(00)80077-3

17. Gorrini C, Harris IS, Mak TW. Modulation of oxidative stress as an anticancer strategy. Nat Rev Drug Discov. (2013) 12:931-47. doi: 10.1038/nrd4002

18. Cui Q, Wang JQ, Assaraf YG, Ren L, Gupta P, Wei L, et al. Modulating ROS to overcome multidrug resistance in cancer. Drug Resist Updat. (2018) 41:1-25. doi: 10.1016/j.drup.2018.11.001

19. Zou Z, Chang $\mathrm{H}$, Li H, Wang $\mathrm{S}$. Induction of reactive oxygen species:an emerging approach for cancer therapy. Apoptosis. (2017) 22:132135. doi: 10.1007/s10495-017-1424-9

20. Trachootham D, Alexandre J, Huang P. Targeting cancer cells by ROSmediated mechanisms:a radical therapeutic approach? Nat Rev Drug Discov. (2009) 8:579-91. doi: 10.1038/nrd2803

21. Yttersian SK, Tveitaras MK, Lu N, Engelsen A, Reed RK, GarmannJohnsen A, et al. Oxygen-dependent regulation of tumor growth and metastasis in human breast cancer xenografts. PLoS ONE. (2017) 12:e183254. doi: 10.1371/journal.pone.0183254

22. Cui Q, Yang Y, Ji N, Wang JQ, Ren L, Yang DH, et al. Gaseous signaling molecules and their application in resistant cancer treatment: from invisible to visible. Future Med Chem. (2019) 11:323-36. doi: 10.4155/fmc-2018-0403

23. Vaupel P, Kelleher DK, Hockel M. Oxygen status of malignant tumors:pathogenesis of hypoxia and significance for tumor therapy. Semin Oncol. (2001) 28:29-35. doi: 10.1016/S0093-7754(01)90210-6

24. Wang P, Wan W, Xiong S, Wang J, Zou D, Lan C, et al. HIF1 $\alpha$ regulates glioma chemosensitivity through the transformation between differentiation and dedifferentiation in various oxygen levels. Sci Rep. (2017) 7:7965. doi: 10.1038/s41598-017-06086-2

25. Badowska-Kozakiewicz AM, Sobol M, Patera J. Expression of multidrug resistance protein P-glycoprotein in correlation with markers of hypoxia (HIF-1 $\alpha$, EPO, EPO-R) in invasive breast cancer with metastasis to lymph nodes. Arch Med Sci. (2017) 13:1303-14. doi: 10.5114/aoms.2016.62723

26. He X, Wang J, Wei W, Shi M, Xin B, Zhang T, et al. Hypoxia regulates ABCG2 activity through the activivation of ERK1/2/HIF- $1 \alpha$ and contributes to chemoresistance in pancreatic cancer cells. Cancer Biol Ther. (2016) 17:188-98. doi: 10.1080/15384047.2016.1139228

27. Sotiropoulou PA, Christodoulou MS, Silvani A, Herold-Mende C, Passarella D. Chemical approaches to targeting drug resistance in cancer stem cells. Drug Discov Today. (2014) 19:1547-62. doi: 10.1016/j.drudis.2014.05.002 
28. Khan IN, Al-Karim S, Bora RS, Chaudhary AG, Saini KS. Cancer stem cells: a challenging paradigm for designing targeted drug therapies. Drug Discov Today. (2015) 20:1205-16. doi: 10.1016/j.drudis.2015.06.013

29. Asghar U, Witkiewicz AK, Turner NC, Knudsen ES. The history and future of targeting cyclin-dependent kinases in cancer therapy. Nat Rev Drug Discov. (2015) 14:130-46. doi: 10.1038/nrd4504

30. Bisteau X, Caldez MJ, Kaldis P. The complex relationship between liver cancer and the cell cycle: a story of multiple regulations. Cancers. (2014) 6:79-111. doi: 10.3390/cancers6010079

31. Beaumont KA, Hill DS, Daignault SM, Lui G, Sharp DM, Gabrielli B, et al. Cell cycle phase-specific drug resistance as an escape mechanism of melanoma cells. J Invest Dermatol. (2016) 136:1479-89. doi: 10.1016/j.jid.2016.02.805

32. Peyressatre M, Prevel C, Pellerano M, Morris MC. Targeting cyclindependent kinases in human cancers:from small molecules to Peptide inhibitors. Cancers. (2015) 7:179-237. doi: 10.3390/cancers7010179

33. Johnson N, Shapiro GI. Cyclin-dependent kinases (cdks) and the DNA damage response:rationale for cdk inhibitor-chemotherapy combinations as an anticancer strategy for solid tumors. Expert Opin Ther Targets. (2010) 14:1199-212. doi: 10.1517/14728222.2010.525221

34. Musgrove EA, Hunter LJ, Lee CS, Swarbrick A, Hui R, Sutherland RL. Cyclin D1 overexpression induces progestin resistance in T-47D breast cancer cells despite p27(Kip1) association with cyclin E-Cdk2. J Biol Chem. (2001) 276:47675-83. doi: 10.1074/jbc.M106371200

35. Hydbring $\mathrm{P}$, Malumbres M, Sicinski P. Non-canonical functions of cell cycle cyclins and cyclin-dependent kinases. Nat Rev Mol Cell Biol. (2016) 17:280-92. doi: 10.1038/nrm.2016.27

36. Li YJ, Lei YH, Yao N, Wang CR, Hu N, Ye WC, et al. Autophagy and multidrug resistance in cancer. Chin J Cancer. (2017) 36:52. doi: 10.1186/s40880-017-0219-2

37. Yu L, Chen Y, Tooze SA. Autophagy pathway: cellular and molecular mechanisms. Autophagy. (2018) 14:20715. doi: 10.1080/15548627.2017.1378838

38. Sui X, Chen R, Wang Z, Huang Z, Kong N, Zhang M, et al. Autophagy and chemotherapy resistance:a promising therapeutic target for cancer treatment. Cell Death Dis. (2013) 4:e838. doi: 10.1038/cddis.2013.350

39. Kalluri R, Weinberg RA. The basics of epithelial-mesenchymal transition. J Clin Invest. (2009) 119:1420-8. doi: 10.1172/JCI39104

40. Fendrich V, Maschuw K, Waldmann J, Buchholz M, Rehm J, Gress TM, et al. Epithelial-mesenchymal transition is a critical step in tumorgenesis of pancreatic neuroendocrine tumors. Cancers. (2012) 4:28194. doi: 10.3390/cancers4010281

41. Nurwidya F, Takahashi F, Murakami A, Takahashi K. Epithelial mesenchymal transition in drug resistance and metastasis of lung cancer. Cancer Res Treat. (2012) 44:151-6. doi: 10.4143/crt.2012.44.3.151

42. Thomas SJ, Snowden JA, Zeidler MP, Danson SJ. The role of JAK/STAT signalling in the pathogenesis, prognosis and treatment of solid tumours. $\mathrm{Br}$ J Cancer. (2015) 113:365-71. doi: 10.1038/bjc.2015.233

43. Kamran MZ, Patil P, Gude RP. Role of STAT3 in cancer metastasis and translational advances. Biomed Res Int. (2013) 2013:421821. doi: 10.1155/2013/421821

44. Duan Z, Foster R, Bell DA, Mahoney J, Wolak K, Vaidya A, et al. Signal transducers and activators of transcription 3 pathway activation in drug-resistant ovarian cancer. Clin Cancer Res. (2006) 12:505563. doi: 10.1158/1078-0432.CCR-06-0861

45. Arora L, Kumar AP, Arfuso F, Chng WJ, Sethi G. The role of signal transducer and activator of transcription 3 (STAT3) and its targeted inhibition in hematological malignancies. Cancers. (2018) 10:327. doi: 10.3390/cancers 10090327

46. Ozaki T, Nakagawara A. Role of p53 in cell death and human cancers. Cancers. (2011) 3:994-1013. doi: 10.3390/cancers3010994

47. Stiewe T, Haran TE. How mutations shape p53 interactions with the genome to promote tumorigenesis and drug resistance. Drug Resist Updat. (2018) 38:27-43. doi: 10.1016/j.drup.2018.05.001

48. Chenette EJ. Cancer: a Ras and NF-kappaB pas de deux. Nat Rev Drug Discov. (2009) 8:932. doi: 10.1038/nrd3056

49. Xia Y, Shen S, Verma IM. NF-kappaB, an active player in human cancers. Cancer Immunol Res. (2014) 2:823-30. doi: 10.1158/2326-6066.CIR-14-0112
50. Szliszka E, Helewski KJ, Mizgala E, Krol W. The dietary flavonol fisetin enhances the apoptosis-inducing potential of TRAIL in prostate cancer cells. Int J Oncol. (2011) 39:771-9. doi: 10.3892/ijo.2011.1116

51. Liu DL, Li YJ, Yang DH, Wang CR, Xu J, Yao N, et al. Ganoderma lucidum derived ganoderenic acid $\mathrm{B}$ reverses ABCB1-mediated multidrug resistance in HepG2/ADM cells. Int J Oncol. (2015) 46:2029-38. doi: 10.3892/ijo.2015.2925

52. Robey RW, Pluchino KM, Hall MD, Fojo AT, Bates SE, Gottesman MM. Revisiting the role of $\mathrm{ABC}$ transporters in multidrug-resistant cancer. Nat Rev Cancer. (2018) 18:452-64. doi: 10.1038/s41568-018-0005-8

53. Newman DJ, Cragg GM. Natural products as sources of new drugs from 1981 to 2014. J Nat Prod. (2016) 79:629-61. doi: 10.1021/acs.jnatprod.5b01055

54. Raffa D, Maggio B, Raimondi MV, Plescia F, Daidone G. Recent discoveries of anticancer flavonoids. Eur J Med Chem. (2017) 142:21328. doi: 10.1016/j.ejmech.2017.07.034

55. Panche AN, Diwan AD, Chandra SR. Flavonoids: an overview. J Nutr Sci. (2016) 5:e47. doi: 10.1017/jns.2016.41

56. Abotaleb M, Samuel SM, Varghese E, Varghese S, Kubatka P, Liskova A, et al. Flavonoids in cancer and apoptosis. Cancers. (2018) 11:E28. doi: 10.3390/cancers11010028

57. Shou JW, Zhang RR, Wu HY, Xia X, Nie H, Jiang RW, et al. Isolation of novel biflavonoids from Cardiocrinum giganteum seeds and characterization of their antitussive activities. J Ethnopharmacol. (2018) 222:171-6. doi: 10.1016/j.jep.2018.05.003

58. Rodriguez-Mateos A, Vauzour D, Krueger CG, Shanmuganayagam D, Reed J, Calani L, et al. Bioavailability, bioactivity and impact on health of dietary flavonoids and related compounds:an update. Arch Toxicol. (2014) 88:180353. doi: 10.1007/s00204-014-1330-7

59. Pietta PG. Flavonoids as antioxidants. J Nat Prod. (2000) 63:103542. doi: 10.1021/np9904509

60. Mozaffarian D, Wu J. Flavonoids, Dairy foods, and cardiovascular and metabolic health: a review of emerging biologic pathways. Circ Res. (2018) 122:369-84. doi: 10.1161/CIRCRESAHA.117.309008

61. Matias I, Buosi AS, Gomes FC. Functions of flavonoids in the central nervous system: astrocytes as targets for natural compounds. Neurochem Int. (2016) 95:85-91. doi: 10.1016/j.neuint.2016.01.009

62. Schagen SK, Zampeli VA, Makrantonaki E, Zouboulis CC. Discovering the link between nutrition and skin aging. Dermatoendocrinology. (2012) 4:298-307. doi: 10.4161/derm.22876

63. Serafini M, Peluso I, Raguzzini A. Flavonoids as anti-inflammatory agents. Proc Nutr Soc. (2010) 69:273-8. doi: 10.1017/S002966511000162X

64. Hosseinimehr SJ. Flavonoids and genomic instability induced by ionizing radiation. Drug Discov Today. (2010) 15:90718. doi: 10.1016/j.drudis.2010.09.005

65. Mani R, Natesan V. Chrysin: sources, beneficial pharmacological activities, and molecular mechanism of action. Phytochemistry. (2018) 145:18796. doi: 10.1016/j.phytochem.2017.09.016

66. Yu XM, Phan T, Patel PN, Jaskula-Sztul R, Chen H. Chrysin activates Notch1 signaling and suppresses tumor growth of anaplastic thyroid carcinoma in vitro and in vivo. Cancer-Am Cancer Soc. (2013) 119:77481. doi: $10.1002 /$ cncr.27742

67. Yang B, Huang J, Xiang T, Yin X, Luo X, Huang J, et al. Chrysin inhibits metastatic potential of human triple-negative breast cancer cells by modulating matrix metalloproteinase-10, epithelial to mesenchymal transition, and PI3K/Akt signaling pathway. J Appl Toxicol. (2014) 34:10512. doi: $10.1002 /$ jat.2941

68. Molnar J, Engi H, Hohmann J, Molnar P, Deli J, Wesolowska O, et al. Reversal of multidrug resitance by natural substances from plants. Curr Top Med Chem. (2010) 10:1757-68. doi: 10.2174/156802610792 928103

69. Wang X, Morris ME. Effects of the flavonoid chrysin on nitrofurantoin pharmacokinetics in rats: potential involvement of ABCG2. Drug Metab Dispos. (2007) 35:268-74. doi: 10.1124/dmd.106.011684

70. Ahmed-Belkacem A, Pozza A, Munoz-Martinez F, Bates SE, Castanys S, Gamarro F, et al. Flavonoid structure-activity studies identify 6prenylchrysin and tectochrysin as potent and specific inhibitors of breast cancer resistance protein ABCG2. Cancer Res. (2005) 65:485260. doi: 10.1158/0008-5472.CAN-04-1817 
71. Li-Weber M. New therapeutic aspects of flavones: the anticancer properties of Scutellaria and its main active constituents Wogonin, Baicalein and Baicalin. Cancer Treat Rev. (2009) 35:57-68. doi: 10.1016/j.ctrv.2008.09.005

72. Zhao X, Qu J, Liu X, Wang J, Ma X, Zhao X, et al. Baicalein suppress EMT of breast cancer by mediating tumor-associated macrophages polarization. Am J Cancer Res. (2018) 8:1528-40.

73. Chen Z, Hou R, Gao S, Song D, Feng Y. Baicalein inhibits proliferation activity of human colorectal cancer cells HCT116 through downregulation of Ezrin. Cell Physiol Biochem. (2018) 49:2035-46. doi: 10.1159/000493714

74. Jiang L, Song $\mathrm{H}$, Guo H, Wang C, Lu Z. Baicalein inhibits proliferation and migration of bladder cancer cell line T24 by down-regulation of microRNA-106. Biomed Pharmacother. (2018) 107:1583-90. doi: 10.1016/j.biopha.2018.08.107

75. Ferreira A, Rodrigues M, Fortuna A, Falcao A, Alves G. Flavonoid compounds as reversing agents of the P-glycoprotein-mediated multidrug resistance: an in vitro evaluation with focus on antiepileptic drugs. Food Res Int. (2018) 103:110-20. doi: 10.1016/j.foodres.2017.10.010

76. Li J, Duan B, Guo Y, Zhou R, Sun J, Bie B, et al. Baicalein sensitizes hepatocellular carcinoma cells to 5-FU and Epirubicin by activating apoptosis and ameliorating P-glycoprotein activity. Biomed Pharmacother. (2018) 98:806-12. doi: 10.1016/j.biopha.2018.01.002

77. Park CH, Han SE, Nam-Goong IS, Kim YI, Kim ES. Combined effects of baicalein and docetaxel on apoptosis in $8505 \mathrm{c}$ anaplastic thyroid cancer cells via downregulation of the ERK and Akt/mTOR Pathways. Endocrinol Metab. (2018) 33:121-32. doi: 10.3803/EnM.2018.33.1.121

78. Meng L, Xia X, Yang Y, Ye J, Dong W, Ma P, et al. Co-encapsulation of paclitaxel and baicalein in nanoemulsions to overcome multidrug resistance via oxidative stress augmentation and P-glycoprotein inhibition. Int J Pharm. (2016) 513:8-16. doi: 10.1016/j.ijpharm.2016.09.001

79. Ko FN, Huang TF, Teng CM. Vasodilatory action mechanisms of apigenin isolated from Apium graveolens in rat thoracic aorta. Biochim Biophys Acta. (1991) 1115:69-74. doi: 10.1016/0304-4165(91)90013-7

80. Bauer D, Redmon N, Mazzio E, Soliman KF. Apigenin inhibits TNF $\alpha /$ IL-1 $\alpha$-induced CCL2 release through IKBK-epsilon signaling in MDA-MB-231 human breast cancer cells. PLoS ONE. (2017) 12:e175558. doi: 10.1371/journal.pone.0175558

81. Erdogan S, Doganlar O, Doganlar ZB, Serttas R, Turkekul K, Dibirdik I, et al. The flavonoid apigenin reduces prostate cancer CD44(+) stem cell survival and migration through PI3K/Akt/NF-kappaB signaling. Life Sci. (2016) 162:77-86. doi: 10.1016/j.lfs.2016.08.019

82. Solmaz S, Adan GA, Cincin B, Ozdogu H, Boga C, Cakmakoglu B, et al. Therapeutic potential of apigenin, a plant flavonoid, for imatinib-sensitive and resistant chronic myeloid leukemia cells. Nutr Cancer. (2014) 66:599612. doi: 10.1080/01635581.2014.894099

83. Saeed M, Kadioglu O, Khalid H, Sugimoto Y, Efferth T. Activity of the dietary flavonoid, apigenin, against multidrug-resistant tumor cells as determined by pharmacogenomics and molecular docking. J Nutr Biochem. (2015) 26:4456. doi: 10.1016/j.jnutbio.2014.09.008

84. Zhu Y, Liu C, Nadiminty N, Lou W, Tummala R, Evans CP, et al. Inhibition of ABCB1 expression overcomes acquired docetaxel resistance in prostate cancer. Mol Cancer Ther. (2013) 12:1829-36. doi: 10.1158/1535-7163.MCT-13-0208

85. Angelini A, Di Ilio C, Castellani ML, Conti P, Cuccurullo F. Modulation of multidrug resistance p-glycoprotein activity by flavonoids and honokiol in human doxorubicin- resistant sarcoma cells (MES-SA/DX-5):implications for natural sedatives as chemosensitizing agents in cancer therapy. J Biol Regul Homeost Agents. (2010) 24:197-205.

86. Seo HS, Ku JM, Choi HS, Woo JK, Lee BH, Kim DS, et al. Apigenin overcomes drug resistance by blocking the signal transducer and activator of transcription 3 signaling in breast cancer cells. Oncol Rep. (2017) 38:71524. doi: $10.3892 /$ or.2017.5752

87. Zhao J, Dasmahapatra AK, Khan SI, Khan IA. Anti-aromatase activity of the constituents from damiana (Turnera diffusa). J Ethnopharmacol. (2008) 120:387-93. doi: 10.1016/j.jep.2008.09.016

88. Kim HR, Park CG, Jung JY. Acacetin. (5,7-dihydroxy-4'-methoxyflavone) exhibits in vitro and in vivo anticancer activity through the suppression of NF-kappaB/Akt signaling in prostate cancer cells. Int J Mol Med. (2014) 33:317-24. doi: 10.3892/ijmm.2013.1571
89. Zeng W, Zhang C, Cheng H, Wu YL, Liu J, Chen Z, et al. Targeting to the non-genomic activity of retinoic acid receptor-gamma by acacetin in hepatocellular carcinoma. Sci Rep. (2017) 7:348. doi: 10.1038/s41598-017-00233-5

90. Katayama K, Masuyama K, Yoshioka S, Hasegawa H, Mitsuhashi J, Sugimoto Y. Flavonoids inhibit breast cancer resistance protein-mediated drug resistance:transporter specificity and structure-activity relationship. Cancer Chemother Pharmacol. (2007) 60:789-97. doi: 10.1007/s00280-007-0426-7

91. Punia R, Raina K, Agarwal R, Singh RP. Acacetin enhances the therapeutic efficacy of doxorubicin in non-small-cell lung carcinoma cells. PLOS ONE. (2017) 12:e182870. doi: 10.1371/journal.pone.0182870

92. Imai Y, Tsukahara S, Asada S, Sugimoto Y. Phytoestrogens/flavonoids reverse breast cancer resistance protein/ABCG2-mediated multidrug resistance. Cancer Res. (2004) 64:4346-52. doi: 10.1158/0008-5472.CAN-04-0078

93. Shin HS, Bae MJ, Choi DW, Shon DH. Skullcap (Scutellaria baicalensis) extract and its active compound, wogonin, inhibit ovalbumin-induced Th2-mediated response. Molecules. (2014) 19:2536-45. doi: 10.3390/molecules19022536

94. Hong ZP, Wang LG, Wang HJ, Ye WF, Wang XZ. Wogonin exacerbates the cytotoxic effect of oxaliplatin by inducing nitrosative stress and autophagy in human gastric cancer cells. Phytomedicine. (2018) 39:16875. doi: 10.1016/j.phymed.2017.12.019

95. Chen XM, Bai Y, Zhong YJ, Xie XL, Long HW, Yang YY, et al. Wogonin has multiple anti-cancer effects by regulating cMyc/SKP2/Fbw7 $\alpha$ and HDAC1/HDAC2 pathways and inducing apoptosis in human lung adenocarcinoma cell line A549. PLoS ONE. (2013) 8:e79201. doi: 10.1371/journal.pone.0079201

96. Tsai CF, Yeh WL, Huang SM, Tan TW, Lu DY. Wogonin induces reactive oxygen species production and cell apoptosis in human glioma cancer cells. Int J Mol Sci. (2012) 13:9877-92. doi: 10.3390/ijms13089877

97. Abdallah HM, Al-Abd AM, El-Dine RS, El-Halawany AM. P-glycoprotein inhibitors of natural origin as potential tumor chemo-sensitizers: a review. $J$ Adv Res. (2015) 6:45-62. doi: 10.1016/j.jare.2014.11.008

98. Lee E, Enomoto R, Koshiba C, Hirano H. Inhibition of P-glycoprotein by wogonin is involved with the potentiation of etoposide-induced apoptosis in cancer cells. Ann N Y Acad Sci. (2009) 1171:1326. doi: 10.1111/j.1749-6632.2009.04722.x

99. Xu X, Zhang Y, Li W, Miao H, Zhang H, Zhou Y, et al. Wogonin reverses multi-drug resistance of human myelogenous leukemia K562/A02 cells via downregulation of MRP1 expression by inhibiting Nrf2/ARE signaling pathway. Biochem Pharmacol. (2014) 92:220-34. doi: 10.1016/j.bcp.2014.09.008

100. Hakkinen SH, Karenlampi SO, Heinonen IM, Mykkanen HM, Torronen AR. Content of the flavonols quercetin, myricetin, and kaempferol in 25 edible berries. J Agric Food Chem. (1999) 47:2274-9. doi: 10.1021/jf 9811065

101. Kim TW, Lee SY, Kim M, Cheon C, Ko SG. Kaempferol induces autophagic cell death via IRE1-JNK-CHOP pathway and inhibition of G9a in gastric cancer cells. Cell Death Dis. (2018) 9:875. doi: 10.1038/s41419-018-0930-1

102. Han X, Liu CF, Gao N, Zhao J, Xu J. Kaempferol suppresses proliferation but increases apoptosis and autophagy by up-regulating microRNA-340 in human lung cancer cells. Biomed Pharmacother. (2018) 108:80916. doi: 10.1016/j.biopha.2018.09.087

103. Jeong $\mathrm{H}$, Phan A, Choi JW. Anti-cancer effects of polyphenolic compounds in epidermal growth factor receptor tyrosine kinase inhibitor-resistant non-small cell lung cancer. Pharmacogn Mag. (2017) 13:595-9. doi: 10.4103/pm.pm_535_16

104. Limtrakul P, Khantamat O, Pintha K. Inhibition of P-glycoprotein function and expression by kaempferol and quercetin. J Chemother. (2005) 17:8695. doi: 10.1179/joc.2005.17.1.86

105. Hooijberg JH, Broxterman HJ, Heijn M, Fles DL, Lankelma J, Pinedo HM. Modulation by (iso)flavonoids of the ATPase activity of the multidrug resistance protein. Febs Lett. (1997) 413:344-8. doi: 10.1016/S0014-5793(97)00940-X

106. To KK, Yu L, Liu S, Fu J, Cho CH. Constitutive AhR activation leads to concomitant ABCG2-mediated multidrug resistance in cisplatinresistant esophageal carcinoma cells. Mol Carcinog. (2012) 51:44964. doi: $10.1002 / \mathrm{mc} .20810$ 
107. Luo H, Daddysman MK, Rankin GO, Jiang BH, Chen YC. Kaempferol enhances cisplatin's effect on ovarian cancer cells through promoting apoptosis caused by down regulation of cMyc. Cancer Cell Int. (2010) 10:16. doi: 10.1186/1475-2867-10-16

108. Du G, Jin L, Han X, Song Z, Zhang H, Liang W. Naringenin:a potential immunomodulator for inhibiting lung fibrosis and metastasis. Cancer Res. (2009) 69:3205-12. doi: 10.1158/0008-5472.CAN-08-3393

109. Gumushan AH, Akgun T. Naringenin inhibits prostate cancer metastasis by blocking voltage-gated sodium channels. Biomed Pharmacother. (2018) 106:770-5. doi: 10.1016/j.biopha.2018.07.008

110. Stompor M, Uram L, Podgorski R. In vitro effect of 8prenylnaringenin and naringenin on fibroblasts and glioblastoma cells-cellular accumulation and cytotoxicity. Molecules. (2017) 22:1092. doi: 10.20944/preprints201706.0071.v1

111. Rauf A, Uddin G, Raza M, Ahmad B, Jehan N, Siddiqui BS, et al. Reversal of multidrug resistance in mouse lymphoma cells by extracts and flavonoids from Pistacia integerrima. Asian Pac J Cancer Prev. (2016) 17:515. doi: 10.7314/APJCP.2016.17.1.51

112. Chung SY, Sung MK, Kim NH, Jang JO, Go EJ, Lee HJ. Inhibition of Pglycoprotein by natural products in human breast cancer cells. Arch Pharm Res. (2005) 28:823-8. doi: 10.1007/BF02977349

113. Nam JS, Sharma AR, Nguyen LT, Chakraborty C, Sharma G, Lee SS. Application of bioactive quercetin in oncotherapy:from nutrition to nanomedicine. Molecules. (2016) 21:E108. doi: 10.3390/molecules21010108

114. Wu Q, Kroon PA, Shao H, Needs PW, Yang X. Differential Effects of quercetin and two of its derivatives, isorhamnetin and isorhamnetin-3glucuronide, in inhibiting the proliferation of human breast-cancer MCF-7 cells. J Agric Food Chem. (2018) 66:7181-9. doi: 10.1021/acs.jafc.8b02420

115. Chang JH, Lai SL, Chen WS, Hung WY, Chow JM, Hsiao M, et al. Quercetin suppresses the metastatic ability of lung cancer through inhibiting Snail-dependent Akt activation and Snail-independent ADAM9 expression pathways. Biochim Biophys Acta Mol Cell Res. (2017) 1864:174658. doi: 10.1016/j.bbamcr.2017.06.017

116. Liu Y, Gong W, Yang ZY, Zhou XS, Gong C, Zhang TR, et al. Quercetin induces protective autophagy and apoptosis through ER stress via the p-STAT3/Bcl-2 axis in ovarian cancer. Apoptosis. (2017) 22:54457. doi: 10.1007/s10495-016-1334-2

117. Mohana S, Ganesan M, Agilan B, Karthikeyan R, Srithar G, Beaulah $\mathrm{MR}$, et al. Screening dietary flavonoids for the reversal of P-glycoproteinmediated multidrug resistance in cancer. Mol Biosyst. (2016) 12:245870. doi: 10.1039/C6MB00187D

118. Chen Z, Huang C, Ma T, Jiang L, Tang L, Shi T, et al. Reversal effect of quercetin on multidrug resistance via FZD7/ $\beta$-catenin pathway in hepatocellular carcinoma cells. Phytomedicine. (2018) 43:37-45. doi: 10.1016/j.phymed.2018.03.040

119. Li S, Zhao Q, Wang B, Yuan S, Wang X, Li K. Quercetin reversed MDR in breast cancer cells through down-regulating P-gp expression and eliminating cancer stem cells mediated by YB-1 nuclear translocation. Phytother Res. (2018) 32:1530-6. doi: 10.1002/ptr.6081

120. Li SZ, Li K, Zhang JH, Dong Z. The effect of quercetin on doxorubicin cytotoxicity in human breast cancer cells. Anticancer Agents Med Chem. (2013) 13:352-5. doi: 10.2174/1871520611313020020

121. Yuan Z, Wang H, Hu Z, Huang Y, Yao F, Sun S, et al. Quercetin inhibits proliferation and drug resistance in $\mathrm{KB} / \mathrm{VCR}$ oral cancer cells and enhances its sensitivity to vincristine. Nutr Cancer. (2015) 67:12636. doi: 10.1080/01635581.2015.965334

122. Iriti M, Kubina R, Cochis A, Sorrentino R, Varoni EM, Kabala-Dzik A, et al. Rutin, a quercetin glycoside, restores chemosensitivity in human breast cancer cells. Phytother Res. (2017) 31:1529-38. doi: 10.1002/ptr.5878

123. Mukhtar E, Adhami VM, Siddiqui IA, Verma AK, Mukhtar H. Fisetin enhances chemotherapeutic effect of cabazitaxel against human prostate cancer cells. Mol Cancer Ther. (2016) 15:2863-74. doi: 10.1158/1535-7163.MCT-16-0515

124. Klimaszewska-Wisniewska A, Halas-Wisniewska M, Tadrowski T, Gagat M, Grzanka D, Grzanka A. Paclitaxel and the dietary flavonoid fisetin:a synergistic combination that induces mitotic catastrophe and autophagic cell death in A549 non-small cell lung cancer cells. Cancer Cell Int. (2016) 16:10. doi: 10.1186/s12935-016-0288-3
125. Sahu BD, Kalvala AK, Koneru M, Mahesh KJ, Kuncha M, Rachamalla SS, et al. Ameliorative effect of fisetin on cisplatin-induced nephrotoxicity in rats via modulation of NF-kappaB activation and antioxidant defence. PLOS ONE. (2014) 9:e105070. doi: 10.1371/journal.pone.0105070

126. Wesolowska O, Wisniewski J, Sroda K, Krawczenko A, BielawskaPohl A, Paprocka M, et al. 8-Prenylnaringenin is an inhibitor of multidrug resistance-associated transporters, P-glycoprotein and MRP1. Eur J Pharmacol. (2010) 644:32-40. doi: 10.1016/j.ejphar.2010.06.069

127. Rong H, Boterberg T, Maubach J, Stove C, Depypere H, Van Slambrouck S, et al. 8-Prenylnaringenin, the phytoestrogen in hops and beer, upregulates the function of the E-cadherin/catenin complex in human mammary carcinoma cells. Eur J Cell Biol. (2001) 80:580-5. doi: 10.1078/0171-9335-00190

128. Sun L, Chen $\mathrm{W}, \mathrm{Qu} \mathrm{L}, \mathrm{Wu}$ J, Si J. Icaritin reverses multidrug resistance of HepG2/ADR human hepatoma cells via downregulation of MDR1 and Pglycoprotein expression. Mol Med Rep. (2013) 8:18837. doi: $10.3892 / \mathrm{mmr} .2013 .1742$

129. Wang ZD, Wang RZ, Xia YZ, Kong LY, Yang L. Reversal of multidrug resistance by icaritin in doxorubicin-resistant human osteosarcoma cells. Chin J Nat Med. (2018) 16:20-8. doi: 10.1016/S1875-5364(18)30026-8

130. Xiao X, Liu Z, Wang R, Wang J, Zhang S, Cai X, et al. Genistein suppresses FLT4 and inhibits human colorectal cancer metastasis. Oncotarget. (2015) 6:3225-39. doi: 10.18632/oncotarget.3064

131. Rigalli JP, Ciriaci N, Mottino AD, Catania VA, Ruiz ML. Modulation of expression and activity of $\mathrm{ABC}$ transporters by the phytoestrogen genistein. impact on drug disposition. Curr Med Chem. (2016) 23:137089. doi: $10.2174 / 0929867323666160406120711$

132. Bircsak KM, Aleksunes LM. Interaction of Isoflavones with the BCRP/ABCG2 Drug Transporter. Curr Drug Metab. (2015) 16:124-40. doi: 10.2174/138920021602150713114921

133. Perez M, Otero JA, Barrera B, Prieto JG, Merino G, Alvarez AI. Inhibition of ABCG2/BCRP transporter by soy isoflavones genistein and daidzein:effect on plasma and milk levels of danofloxacin in sheep. Vet J. (2013) 196:2038. doi: 10.1016/j.tvjl.2012.09.012

134. Wang Y, Li JJ, Chen YM. Biochanin A extirpates the epithelial-mesenchymal transition in a human lung cancer. Exp Ther Med. (2018) 15:28306. doi: 10.3892/etm.2018.5731

135. Moon YJ, Shin BS, An G, Morris ME. Biochanin A inhibits breast cancer tumor growth in a murine xenograft model. Pharm Res. (2008) 25:215863. doi: 10.1007/s11095-008-9583-6

136. Zhang S, Yang X, Morris ME. Combined effects of multiple flavonoids on breast cancer resistance protein (ABCG2)-mediated transport. Pharm Res. (2004) 21:1263-73. doi: 10.1023/B:PHAM.0000033015.84146.4c

137. Taniguchi H, Yoshida $T$, Horinaka M, Yasuda $T$, Goda AE, Konishi $\mathrm{M}$, et al. Baicalein overcomes tumor necrosis factor-related apoptosisinducing ligand resistance via two different cell-specific pathways in cancer cells but not in normal cells. Cancer Res. (2008) 68:891827. doi: 10.1158/0008-5472.CAN-08-1120

138. Kansanen E, Kuosmanen SM, Leinonen H, Levonen AL. The Keap1-Nrf2 pathway: mechanisms of activation and dysregulation in cancer. Redox Biol. (2013) 1:45-9. doi: 10.1016/j.redox.2012.10.001

139. Gao AM, Ke ZP, Shi F, Sun GC, Chen H. Chrysin enhances sensitivity of BEL-7402/ADM cells to doxorubicin by suppressing PI3K/Akt/Nrf2 and ERK/Nrf2 pathway. Chem Biol Interact. (2013) 206:100-8. doi: 10.1016/j.cbi.2013.08.008

140. Singh S, Khan AR, Gupta AK. Role of glutathione in cancer pathophysiology and therapeutic interventions. J Exp Ther Oncol. (2012) 9:303-16.

141. Bansal A, Simon MC. Glutathione metabolism in cancer progression and treatment resistance. J Cell Biol. (2018) 217:2291-8. doi: 10.1083/jcb.201804161

142. Kachadourian R, Day BJ. Flavonoid-induced glutathione depletion: potential implications for cancer treatment. Free Radic Biol Med. (2006) 41:6576. doi: 10.1016/j.freeradbiomed.2006.03.002

143. Brechbuhl HM, Kachadourian R, Min E, Chan D, Day BJ. Chrysin enhances doxorubicin-induced cytotoxicity in human lung epithelial cancer cell lines:the role of glutathione. Toxicol Appl Pharmacol. (2012) 258:19. doi: 10.1016/j.taap.2011.08.004

144. Yang L, Wang Q, Li D, Zhou Y, Zheng X, Sun H, et al. Wogonin enhances antitumor activity of tumor necrosis factor-related apoptosis-inducing 
ligand in vivo through ROS-mediated downregulation of cFLIPL and IAP proteins. Apoptosis. (2013) 18:618-26. doi: 10.1007/s10495-013-0808-8

145. Xu X, Zhang X, Zhang Y, Yang L, Liu Y, Huang S, et al. Wogonin reversed resistant human myelogenous leukemia cells via inhibiting Nrf2 signaling by Stat3/NF-kappaB inactivation. Sci Rep. (2017) 7:39950. doi: 10.1038/srep39950

146. Qian C, Wang Y, Zhong Y, Tang J, Zhang J, Li Z, et al. Wogoninenhanced reactive oxygen species-induced apoptosis and potentiated cytotoxic effects of chemotherapeutic agents by suppression Nrf2mediated signaling in HepG2 cells. Free Radic Res. (2014) 48:60721. doi: $10.3109 / 10715762.2014 .897342$

147. Laberge RM, Karwatsky J, Lincoln MC, Leimanis ML, Georges E. Modulation of GSH levels in ABCC1 expressing tumor cells triggers apoptosis through oxidative stress. Biochem Pharmacol. (2007) 73:172737. doi: 10.1016/j.bcp.2007.02.005

148. Zhong Y, Zhang F, Sun Z, Zhou W, Li ZY, You QD, et al. Drug resistance associates with activation of Nrf2 in MCF-7/DOX cells, and wogonin reverses it by down-regulating Nrf2-mediated cellular defense response. Mol Carcinog. (2013) 52:824-34. doi: 10.1002/mc.21921

149. Li Z, Zhang Y, Chen L, Li H. The dietary compound luteolin inhibits pancreatic cancer growth by targeting BCL-2. Food Funct. (2018) 9:301827. doi: 10.1039/C8FO00033F

150. Palko-Labuz A, Sroda-Pomianek K, Uryga A, Kostrzewa-Suslow E, Michalak $\mathrm{K}$. Anticancer activity of baicalein and luteolin studied in colorectal adenocarcinoma LoVo cells and in drug-resistant LoVo/Dx cells. Biomed Pharmacother. (2017) 88:232-41. doi: 10.1016/j.biopha.2017.01.053

151. Sompakdee V, Prawan A, Senggunprai L, Kukongviriyapan U, Samathiwat P, Wandee J, et al. Suppression of Nrf2 confers chemosensitizing effect through enhanced oxidant-mediated mitochondrial dysfunction. Biomed Pharmacother. (2018) 101:627-34. doi: 10.1016/j.biopha. 2018.02.112

152. Chian S, Thapa R, Chi Z, Wang XJ, Tang X. Luteolin inhibits the Nrf2 signaling pathway and tumor growth in vivo. Biochem Biophys Res Commun. (2014) 447:602-8. doi: 10.1016/j.bbrc.2014.04.039

153. Chian S, Li YY, Wang XJ, Tang XW. Luteolin sensitizes two oxaliplatinresistant colorectal cancer cell lines to chemotherapeutic drugs via inhibition of the Nrf2 pathway. Asian Pac J Cancer Prev. (2014) 15:29116. doi: 10.7314/APJCP.2014.15.6.2911

154. Tang X, Wang H, Fan L, Wu X, Xin A, Ren H, et al. Luteolin inhibits Nrf2 leading to negative regulation of the Nrf2/ARE pathway and sensitization of human lung carcinoma A549 cells to therapeutic drugs. Free Radic Biol Med. (2011) 50:1599-609. doi: 10.1016/j.freeradbiomed.2011.03.008

155. Sabzichi M, Hamishehkar H, Ramezani F, Sharifi S, Tabasinezhad M, Pirouzpanah $M$, et al. Luteolin-loaded phytosomes sensitize human breast carcinoma MDA-MB 231 cells to doxorubicin by suppressing Nrf2 mediated signalling. Asian Pac J Cancer Prev. (2014) 15:53116. doi: 10.7314/APJCP.2014.15.13.5311

156. Lorendeau D, Dury L, Genoux-Bastide E, Lecerf-Schmidt F, Simoes-Pires C, Carrupt PA, et al. Collateral sensitivity of resistant MRP1-overexpressing cells to flavonoids and derivatives through GSH efflux. Biochem Pharmacol. (2014) 90:235-45. doi: 10.1016/j.bcp.2014.05.017

157. Pluchino KM, Hall MD, Goldsborough AS, Callaghan R, Gottesman MM. Collateral sensitivity as a strategy against cancer multidrug resistance. Drug Resist Updat. (2012) 15:98-105. doi: 10.1016/j.drup.2012.03.002

158. Kulling SE, Honig DM, Metzler M. Oxidative metabolism of the soy isoflavones daidzein and genistein in humans in vitro and in vivo. J Agric Food Chem. (2001) 49:3024-33. doi: 10.1021/jf0012695

159. Liu X, Sun C, Liu B, Jin X, Li P, Zheng X, et al. Genistein mediates the selective radiosensitizing effect in NSCLC A549 cells via inhibiting methylation of the keap1 gene promoter region. Oncotarget. (2016) 7:2726779. doi: 10.18632 /oncotarget. 8403

160. Lo YL, Wang W, Ho CT. 7,3','-Trihydroxyisoflavone modulates multidrug resistance transporters and induces apoptosis via production of reactive oxygen species. Toxicology. (2012) 302:221-32. doi: 10.1016/j.tox.2012.08.003

161. Chen F, Zhuang M, Zhong C, Peng J, Wang X, Li J, et al. Baicalein reverses hypoxia-induced 5-FU resistance in gastric cancer AGS cells through suppression of glycolysis and the PTEN/Akt/HIF1a signaling pathway. Oncol Rep. (2015) 33:457-63. doi: 10.3892/ or. 2014.3550

162. Wang H, Zhao L, Zhu LT, Wang Y, Pan D, Yao J, et al. Wogonin reverses hypoxia resistance of human colon cancer HCT116 cells via downregulation of HIF- $1 \alpha$ and glycolysis, by inhibiting PI3K/Akt signaling pathway. Mol Carcinog. (2014) 53 (Suppl 1):E107-18. doi: 10.1002/mc.22052

163. Du G, Lin H, Wang M, Zhang S, Wu X, Lu L, et al. Quercetin greatly improved therapeutic index of doxorubicin against $4 \mathrm{~T} 1$ breast cancer by its opposing effects on HIF-1 $\alpha$ in tumor and normal cells. Cancer Chemother Pharmacol. (2010) 65:277-87. doi: 10.1007/s00280-009-1032-7

164. Kim HS, Wannatung T, Lee S, Yang WK, Chung SH, Lim JS, et al. Quercetin enhances hypoxia-mediated apoptosis via direct inhibition of AMPK activity in HCT116 colon cancer. Apoptosis. (2012) 17:93849. doi: 10.1007/s10495-012-0719-0

165. Wu R, Murali R, Kabe Y, French SW, Chiang YM, Liu S, et al. Baicalein targets GTPase-mediated autophagy to eliminate liver tumor initiating stem cell-like cells resistant to mTORC1 inhibition. Hepatology. (2018) 68:172640. doi: 10.1002/hep.30071

166. Erdogan S, Turkekul K, Serttas R, Erdogan Z. The natural flavonoid apigenin sensitizes human $\mathrm{CD} 44(+)$ prostate cancer stem cells to cisplatin therapy. Biomed Pharmacother. (2017) 88:210-7. doi: 10.1016/j.biopha.2017.01.056

167. Kim B, Jung N, Lee S, Sohng JK, Jung HJ. Apigenin inhibits cancer stem cell-like phenotypes in human glioblastoma cells via suppression of c-met signaling. Phytother Res. (2016) 30:1833-40. doi: 10.1002/ptr.5689

168. Huynh DL, Kwon T, Zhang JJ, Sharma N, Gera M, Ghosh M, et al. Wogonin suppresses stem cell-like traits of CD133 positive osteosarcoma cell via inhibiting matrix metallopeptidase-9 expression. BMC Complement Altern Med. (2017) 17:304. doi: 10.1186/s12906-017-1788-y

169. Davies AH, Reipas K, Hu K, Berns R, Firmino N, Stratford AL, et al. Inhibition of RSK with the novel small-molecule inhibitor LJI308 overcomes chemoresistance by eliminating cancer stem cells. Oncotarget. (2015) 6:20570-7. doi: 10.18632/oncotarget.4135

170. Cao C, Sun L, Mo W, Sun L, Luo J, Yang Z, et al. Quercetin Mediates $\beta$-catenin in pancreatic cancer stem-like cells. Pancreas. (2015) 44:13349. doi: 10.1097/MPA.0000000000000400

171. Dandawate PR, Subramaniam D, Jensen RA, Anant S. Targeting cancer stem cells and signaling pathways by phytochemicals: novel approach for breast cancer therapy. Semin Cancer Biol. (2016) 40-41:192-208. doi: 10.1016/j.semcancer.2016.09.001

172. Atashpour S, Fouladdel S, Movahhed TK, Barzegar E, Ghahremani MH, Ostad SN, et al. Quercetin induces cell cycle arrest and apoptosis in CD133(+) cancer stem cells of human colorectal HT29 cancer cell line and enhances anticancer effects of doxorubicin. Iran J Basic Med Sci. (2015) 18:635-43.

173. Tu SH, Ho CT, Liu MF, Huang CS, Chang HW, Chang $\mathrm{CH}$, et al. Luteolin sensitises drug-resistant human breast cancer cells to tamoxifen via the inhibition of cyclin E2 expression. Food Chem. (2013) 141:155361. doi: 10.1016/j.foodchem.2013.04.077

174. Srinivasan A, Thangavel C, Liu Y, Shoyele S, Den RB, Selvakumar $\mathrm{P}$, et al. Quercetin regulates $\beta$-catenin signaling and reduces the migration of triple negative breast cancer. Mol Carcinog. (2016) 55:74356. doi: $10.1002 / \mathrm{mc} .22318$

175. Catanzaro D, Ragazzi E, Vianello C, Caparrotta L, Montopoli M. Effect of quercetin on cell cycle and cyclin expression in ovarian carcinoma and osteosarcoma cell lines. Nat Prod Commun. (2015) 10:13658. doi: $10.1177 / 1934578 X 1501000813$

176. Gao C, Zhou Y, Jiang Z, Zhao Y, Zhang D, Cong X, et al. Cytotoxic and chemosensitization effects of Scutellarin from traditional Chinese herb Scutellaria altissima L. in human prostate cancer cells. Oncol Rep. (2017) 38:1491-9. doi: 10.3892/or.2017.5850

177. Gao AM, Zhang XY, Hu JN, Ke ZP. Apigenin sensitizes hepatocellular carcinoma cells to doxorubic through regulating miR-520b/ATG7 axis. Chem Biol Interact. (2018) 280:45-50. doi: 10.1016/j.cbi.2017.11.020

178. Liu Q, Zhu D, Hao B, Zhang Z, Tian Y. Luteolin promotes the sensitivity of cisplatin in ovarian cancer by decreasing PRPA1-medicated autophagy. Cell Mol Biol. (2018) 64:17-22. doi: 10.14715/cmb/2018.64.6.4 
179. Pan XW, Li L, Huang Y, Huang H, Xu DF, Gao Y, et al. Icaritin acts synergistically with epirubicin to suppress bladder cancer growth through inhibition of autophagy. Oncol Rep. (2016) 35:334-42. doi: 10.3892/or.2015.4335

180. Liang SQ, Marti TM, Dorn P, Froment L, Hall SR, Berezowska S, et al. Blocking the epithelial-to-mesenchymal transition pathway abrogates resistance to anti-folate chemotherapy in lung cancer. Cell Death Dis. (2015) 6:e1824. doi: 10.1038/cddis.2015.195

181. Dia VP, Pangloli P. Epithelial-to-mesenchymal transition in paclitaxelresistant ovarian cancer cells is downregulated by luteolin. J Cell Physiol. (2017) 232:391-401. doi: 10.1002/jcp.25436

182. Lirdprapamongkol K, Sakurai H, Abdelhamed S, Yokoyama S, Athikomkulchai S, Viriyaroj A, et al. Chrysin overcomes TRAIL resistance of cancer cells through Mcl-1 downregulation by inhibiting STAT3 phosphorylation. Int J Oncol. (2013) 43:329-37. doi: 10.3892/ijo.2013.1926

183. Yu S, Gong LS, Li NF, Pan YF, Zhang L. Galangin (GG) combined with cisplatin (DDP) to suppress human lung cancer by inhibition of STAT3-regulated NF-kappaB and Bcl-2/Bax signaling pathways. Biomed Pharmacother. (2018) 97:213-24. doi: 10.1016/j.biopha.2017.10.059

184. Yang Z, Liu Y, Liao J, Gong C, Sun C, Zhou X, et al. Quercetin induces endoplasmic reticulum stress to enhance cDDP cytotoxicity in ovarian cancer: involvement of STAT3 signaling. Febs J. (2015) 282:111125. doi: $10.1111 /$ febs. 13206

185. Li X, Huang JM, Wang JN, Xiong XK, Yang XF, Zou F. Combination of chrysin and cisplatin promotes the apoptosis of Hep G2 cells by up-regulating p53. Chem Biol Interact. (2015) 232:12-20. doi: 10.1016/j.cbi.2015.03.003

186. Liu R, Ji P, Liu B, Qiao H, Wang X, Zhou L, et al. Apigenin enhances the cisplatin cytotoxic effect through p53-modulated apoptosis. Oncol Lett. (2017) 13:1024-30. doi: 10.3892/ol.2016.5495

187. Xavier CP, Lima CF, Rohde M, Pereira-Wilson C. Quercetin enhances 5-fluorouracil-induced apoptosis in MSI colorectal cancer cells through p53 modulation. Cancer Chemother Pharmacol. (2011) 68:1449-57. doi: 10.1007/s00280-011-1641-9

188. Sun CY, Zhu Y, Li XF, Wang XQ, Tang LP, Su ZQ, et al. Scutellarin increases cisplatin-induced apoptosis and autophagy to overcome cisplatin resistance in non-small cell lung cancer via ERK/p53 and c-met/AKT signaling pathways. Front Pharmacol. (2018) 9:92. doi: 10.3389/fphar.2018.00092

189. Solomon LA, Ali S, Banerjee S, Munkarah AR, Morris RT, Sarkar FH. Sensitization of ovarian cancer cells to cisplatin by genistein: the role of NF-kappaB. J Ovarian Res. (2008) 1:9. doi: 10.1186/1757-2215-1-9

190. Li Y, Ahmed F, Ali S, Philip PA, Kucuk O, Sarkar FH. Inactivation of nuclear factor kappaB by soy isoflavone genistein contributes to increased apoptosis induced by chemotherapeutic agents in human cancer cells. Cancer Res. (2005) 65:6934-42. doi: 10.1158/0008-5472.CAN-04-4604

191. Banerjee S, Zhang Y, Ali S, Bhuiyan M, Wang Z, Chiao PJ, et al. Molecular evidence for increased antitumor activity of gemcitabine by genistein in vitro and in vivo using an orthotopic model of pancreatic cancer. Cancer Res. (2005) 65:9064-72. doi: 10.1158/0008-5472.CAN-05-1330

192. Banerjee S, Kong D, Azmi AS, Wang Z, Ahmad A, Sethi S, et al. Restoring sensitivity to oxaliplatin by a novel approach in gemcitabine-resistant pancreatic cancer cells in vitro and in vivo. Int J Cancer. (2011) 128:124050. doi: $10.1002 /$ ijc. 25658

193. Zhang B, Shi ZL, Liu B, Yan XB, Feng J, Tao HM. Enhanced anticancer effect of gemcitabine by genistein in osteosarcoma: the role of Akt and nuclear factor-kappaB. Anticancer Drugs. (2010) 21:28896. doi: 10.1097/CAD.0b013e328334da17

194. Shen J, Tai YC, Zhou J, Stephen WC, Cheang PT, Fred WW, et al. Synergistic antileukemia effect of genistein and chemotherapy in mouse xenograft model and potential mechanism through MAPK signaling. Exp Hematol. (2007) 35:75-83. doi: 10.1016/j.exphem.2006.09.007

195. Ma Y, Wang J, Liu L, Zhu H, Chen X, Pan S, et al. Genistein potentiates the effect of arsenic trioxide against human hepatocellular carcinoma: role of Akt and nuclear factor-kappaB. Cancer Lett. (2011) 301:7584. doi: 10.1016/j.canlet.2010.10.022

196. Szliszka E, Czuba ZP, Mertas A, Paradysz A, Krol W. The dietary isoflavone biochanin-A sensitizes prostate cancer cells to TRAIL-induced apoptosis. Urol Oncol. (2013) 31:331-42. doi: 10.1016/j.urolonc.2011.01.019
197. Lee KT, Sohn IC, Kim YK, Choi JH, Choi JW, Park HJ, et al. Tectorigenin, an isoflavone of Pueraria thunbergiana Benth., induces differentiation and apoptosis in human promyelocytic leukemia HL-60 cells. Biol Pharm Bull. (2001) 24:1117-21. doi: 10.1248/bpb.24.1117

198. Yang YI, Lee KT, Park HJ, Kim TJ, Choi YS, Shih I, et al. Tectorigenin sensitizes paclitaxel-resistant human ovarian cancer cells through downregulation of the Akt and NFkappaB pathway. Carcinogenesis. (2012) 33:2488-98. doi: 10.1093/carcin/bgs302

199. Jeng LB, Kumar VB, Chen MC, Hsu HH, Ho TJ, Day CH, et al. Fisetin mediated apoptotic cell death in parental and Oxaliplatin/irinotecan resistant colorectal cancer cells in vitro and in vivo. J Cell Physiol. (2018) 233:7134-42. doi: 10.1002/jcp.26532

200. Liu D, Yan L, Wang L, Tai W, Wang W, Yang C. Genistein enhances the effect of cisplatin on the inhibition of non-small cell lung cancer A549 cell growth in vitro and in vivo. Oncol Lett. (2014) 8:2806-10. doi: 10.3892/ol.2014.2597

201. Zhuo W, Zhang L, Zhu Y, Zhu B, Chen Z. Fisetin, a dietary bioflavonoid, reverses acquired Cisplatin-resistance of lung adenocarcinoma cells through MAPK/Survivin/Caspase pathway. Am J Transl Res. (2015) 7:2045-52.

202. Zhang L, Huang Y, Zhuo W, Zhu Y, Zhu B, Chen Z. Fisetin, a dietary phytochemical, overcomes Erlotinib-resistance of lung adenocarcinoma cells through inhibition of MAPK and AKT pathways. Am J Transl Res. (2016) 8:4857-68.

203. Oishi M, Iizumi Y, Taniguchi T, Goi W, Miki T, Sakai T, Apigenin sensitizes prostate cancer cells to Apo2L/TRAIL by targeting adenine nucleotide translocase-2. PLoS ONE. (2013) 8:e55922. doi: 10.1371/journal.pone.0055922

204. Liu ZC, Cao K, Xiao ZH, Qiao L, Wang XQ, Shang B, et al. VRK1 promotes cisplatin resistance by up-regulating c-MYC via c-Jun activation and serves as a therapeutic target in esophageal squamous cell carcinoma. Oncotarget. (2017) 8:65642-58. doi: 10.18632/oncotarget.20020

205. Oh SJ, Kim O, Lee JS, Kim JA, Kim MR, Choi HS, et al. Inhibition of angiogenesis by quercetin in tamoxifen-resistant breast cancer cells. Food Chem Toxicol. (2010) 48:3227-34. doi: 10.1016/j.fct.2010.08.028

206. Tummala R, Lou W, Gao AC, Nadiminty N. Quercetin targets hnRNPA1 to overcome enzalutamide resistance in prostate cancer cells. Mol Cancer Ther. (2017) 16:2770-9. doi: 10.1158/1535-7163.MCT-17-0030

207. Hwang JT, Ha J, Park OJ. Combination of 5-fluorouracil and genistein induces apoptosis synergistically in chemo-resistant cancer cells through the modulation of AMPK and COX-2 signaling pathways. Biochem Biophys Res Commun. (2005) 332:433-40. doi: 10.1016/j.bbrc.2005.04.143

208. Jin CY, Park C, Moon SK, Kim GY, Kwon TK, Lee SJ, et al. Genistein sensitizes human hepatocellular carcinoma cells to TRAIL-mediated apoptosis by enhancing Bid cleavage. Anticancer Drugs. (2009) 20:71322. doi: 10.1097/CAD.0b013e32832e8998

209. Shen M, Chan TH, Dou QP. Targeting tumor ubiquitin-proteasome pathway with polyphenols for chemosensitization. Anticancer Agents Med Chem. (2012) 12:891-901. doi: 10.2174/187152012802649978

210. Wang HW, Lin CP, Chiu JH, Chow KC, Kuo KT, Lin CS, et al. Reversal of inflammation-associated dihydrodiol dehydrogenases (AKR1C1 and AKR1C2) overexpression and drug resistance in nonsmall cell lung cancer cells by wogonin and chrysin. Int J Cancer. (2007) 120:201927. doi: $10.1002 /$ ijc. 22402

211. Suh YA, Jo SY, Lee HY, Lee C. Inhibition of IL-6/STAT3 axis and targeting Axl and Tyro3 receptor tyrosine kinases by apigenin circumvent taxol resistance in ovarian cancer cells. Int J Oncol. (2015) 46:140511. doi: $10.3892 /$ ijo. 2014.2808

212. Hu XY, Liang JY, Guo XJ, Liu L, Guo YB. 5-Fluorouracil combined with apigenin enhances anticancer activity through mitochondrial membrane potential (DeltaPsim)-mediated apoptosis in hepatocellular carcinoma. Clin Exp Pharmacol Physiol. (2015) 42:146-53. doi: 10.1111/1440-1681. 12333

213. Shao H, Jing K, Mahmoud E, Huang H, Fang X, Yu C. Apigenin sensitizes colon cancer cells to antitumor activity of ABT-263. Mol Cancer Ther. (2013) 12:2640-50. doi: 10.1158/1535-7163.MCT-13-0066

214. Long X, Fan M, Bigsby RM, Nephew KP. Apigenin inhibits antiestrogenresistant breast cancer cell growth through estrogen receptor-alphadependent and estrogen receptor-alpha-independent mechanisms. Mol Cancer Ther. (2008) 7:2096-108. doi: 10.1158/1535-7163.MCT-07-2350 
215. Zhao Y, Tian B, Wang Y, Ding H. Kaempferol sensitizes human ovarian cancer cells-OVCAR-3 and SKOV-3 to tumor necrosis factor-related apoptosis-inducing ligand (TRAIL)-induced apoptosis via JNK/ERK-CHOP pathway and up-regulation of death receptors 4 and 5. Med Sci Monit. (2017) 23:5096-105. doi: 10.12659/MSM.903552

216. Siegelin MD, Reuss DE, Habel A, Herold-Mende C, von Deimling A. The flavonoid kaempferol sensitizes human glioma cells to TRAIL-mediated apoptosis by proteasomal degradation of survivin. Mol Cancer Ther. (2008) 7:3566-74. doi: 10.1158/1535-7163.MCT-08-0236

217. Wu X, Zhang H, Salmani JM, Fu R, Chen B. Advances of wogonin, an extract from Scutellaria baicalensis, for the treatment of multiple tumors. Onco Targets Ther. (2016) 9:2935-43. doi: 10.2147/OTT.S105586

218. Fu P, Du F, Liu Y, Hong Y, Yao M, Zheng S. Wogonin increases doxorubicin sensitivity by down-regulation of IGF-1R/AKT signaling pathway in human breast cancer. Cell Mol Biol. (2015) 61:123-7.

219. Rong LW, Wang RX, Zheng XL, Feng XQ, Zhang L, Zhang $\mathrm{L}$, et al. Combination of wogonin and sorafenib effectively kills human hepatocellular carcinoma cells through apoptosis potentiation and autophagy inhibition. Oncol Lett. (2017) 13:5028-34. doi: 10.3892/ol.2017.6059

220. Russo GL, Russo M, Spagnuolo C. The pleiotropic flavonoid quercetin:from its metabolism to the inhibition of protein kinases in chronic lymphocytic leukemia. Food Funct. (2014) 5:2393-401. doi: 10.1039/C4FO00413B

221. Shu Y, Xie B, Liang Z, Chen J. Quercetin reverses the doxorubicin resistance of prostate cancer cells by downregulating the expression of c-met. Oncol Lett. (2018) 15:2252-8. doi: 10.3892/ol.2017.7561

222. Chen FY, Cao LF, Wan HX, Zhang MY, Cai JY, Shen LJ, et al. Quercetin enhances adriamycin cytotoxicity through induction of apoptosis and regulation of mitogen-activated protein kinase/extracellular signal-regulated kinase/c-Jun N-terminal kinase signaling in multidrug-resistant leukemia K562 cells. Mol Med Rep. (2015) 11:341-8. doi: 10.3892/mmr.2014.2734

223. Kim JH, Kim MJ, Choi KC, Son J. Quercetin sensitizes pancreatic cancer cells to TRAIL-induced apoptosis through JNK-mediated cFLIP turnover. Int J Biochem Cell Biol. (2016) 78:327-34. doi: 10.1016/j.biocel.2016.07.033

224. Wang H, Tao L, Qi K, Zhang H, Feng D, Wei W, et al. Quercetin reverses tamoxifen resistance in breast cancer cells. J Buon. (2015) 20:707-13.

225. Priyadarshani G, Amrutkar S, Nayak A, Banerjee UC, Kundu CN, Guchhait SK. Scaffold-hopping of bioactive flavonoids: discovery of aryl-pyridopyrimidinones as potent anticancer agents that inhibit catalytic role of topoisomerase II $\alpha$. Eur J Med Chem. (2016) 122:43-54. doi: 10.1016/j.ejmech.2016.06.024

226. Tsuchiya H. Membrane interactions of phytochemicals as their molecular mechanism applicable to the discovery of drug leads from plants. Molecules. (2015) 20:18923-66. doi: 10.3390/molecules201018923

227. Kuete V, Sandjo LP, Djeussi DE, Zeino M, Kwamou GM, Ngadjui B, et al. Cytotoxic flavonoids and isoflavonoids from Erythrina sigmoidea towards multi-factorial drug resistant cancer cells. Invest New Drugs. (2014) 32:105362. doi: 10.1007/s10637-014-0137-y

228. Margina D, Ilie M, Manda G, Neagoe I, Mocanu M, Ionescu D, et al. Quercetin and epigallocatechin gallate effects on the cell membranes biophysical properties correlate with their antioxidant potential. Gen Physiol Biophys. (2012) 31:47-55. doi: 10.4149/gpb_2012_005

229. Selvaraj S, Krishnaswamy S, Devashya V, Sethuraman S, Krishnan UM. Influence of membrane lipid composition on flavonoid-membrane interactions: implications on their biological activity. Prog Lipid Res. (2015) 58:1-13. doi: 10.1016/j.plipres.2014.11.002

230. Cui Q, Wen S, Huang P. Targeting cancer cell mitochondria as a therapeutic approach: recent updates. Future Med Chem. (2017) 9:92949. doi: $10.4155 / \mathrm{fmc}-2017-0011$

231. Ingólfsson HI, Thakur P, Herold KF, Hobart EA, Ramsey NB, Periole $\mathrm{X}$, et al. Phytochemicals perturb membranes and promiscuously alter protein function. Acs Chem Biol. (2014) 9:1788-98. doi: 10.1021/ cb500086e
232. Cui Q, Yang DH, Chen ZS. Special issue: natural products: anticancer and Beyond. Molecules. (2018) 23:1246-9. doi: 10.3390/molecules23061246

233. Kim EH, Jang H, Shin D, Baek SH, Roh JL. Targeting Nrf2 with wogonin overcomes cisplatin resistance in head and neck cancer. Apoptosis. (2016) 21:1265-78. doi: 10.1007/s10495-016-1284-8

234. Dury L, Nasr R, Lorendeau D, Comsa E, Wong I, Zhu X, et al. Flavonoid dimers are highly potent killers of multidrug resistant cancer cells overexpressing MRP1. Biochem Pharmacol. (2017) 124:108. doi: 10.1016/j.bcp.2016.10.013

235. Furedi A, Toth S, Szebenyi K, Pape VF, Turk D, Kucsma N, et al. Identification and validation of compounds selectively killing resistant cancer: delineating cell line-specific effects from P-glycoprotein-induced toxicity. Mol Cancer Ther. (2017) 16:45-56. doi: 10.1158/1535-7163.MCT-16-0333-T

236. Lin TH, Hsu WH, Tsai PH, Huang YT, Lin CW, Chen KC, et al. Dietary flavonoids, luteolin and quercetin, inhibit invasion of cervical cancer by reduction of UBE2S through epithelial-mesenchymal transition signaling. Food Funct. (2017) 8:1558-68. doi: 10.1039/C6FO00551A

237. Burkard M, Leischner C, Lauer UM, Busch C, Venturelli S, Frank J. Dietary flavonoids and modulation of natural killer cells:implications in malignant and viral diseases. J Nutr Biochem. (2017) 46:1-12. doi: 10.1016/j.jnutbio.2017.01.006

238. Amawi H, Ashby CJ, Tiwari AK. Cancer chemoprevention through dietary flavonoids: what's limiting? Chin J Cancer. (2017) 36:50. doi: 10.1186/s40880-017-0217-4

239. Stompor M, Switalska M, Wietrzyk J. Synthesis and biological evaluation of acyl derivatives of hydroxyflavones as potent antiproliferative agents against drug resistance cell lines. Z Naturforsch C. (2018) 73:8793. doi: 10.1515/znc-2017-0093

240. Bai J, Yang BJ, Luo X. Effects of 5-hydroxy-4'-nitro-7-propionyloxy-genistein on inhibiting proliferation and invasion via activating reactive oxygen species in human ovarian cancer A2780/DDP cells. Oncol Lett. (2018) 15:5227-35. doi: 10.3892/ol.2018.7938

241. Kim MK, Kim Y, Choo H, Chong Y. Quercetin-glutamic acid conjugate with a non-hydrolysable linker; a novel scaffold for multidrug resistance reversal agents through inhibition of P-glycoprotein. Bioorg Med Chem. (2017) 25:1219-26. doi: 10.1016/j.bmc.2016.12.034

242. Chan KF, Zhao Y, Burkett BA, Wong IL, Chow LM, Chan TH. Flavonoid dimers as bivalent modulators for P-glycoprotein-based multidrug resistance: synthetic apigenin homodimers linked with defined-length poly(ethylene glycol) spacers increase drug retention and enhance chemosensitivity in resistant cancer cells. J Med Chem. (2006) 49:674259. doi: 10.1021/jm060593+

243. Martins IL, Charneira C, Gandin V, Ferreira DSJ, Justino GC, Telo JP, et al. Selenium-containing chrysin and quercetin derivatives: attractive scaffolds for cancer therapy. J Med Chem. (2015) 58:4250-65. doi: 10.1021/acs.jmedchem.5b00230

244. Li J, Zhu F, Lubet RA, De Luca A, Grubbs C, Ericson ME, et al. Quercetin3-methyl ether inhibits lapatinib-sensitive and -resistant breast cancer cell growth by inducing G(2)/M arrest and apoptosis. Mol Carcinog. (2013) 52:134-43. doi: $10.1002 / \mathrm{mc} .21839$

Conflict of Interest Statement: The authors declare that the research was conducted in the absence of any commercial or financial relationships that could be construed as a potential conflict of interest.

Copyright (c) 2019 Ye, Liu, Shen, Li, Hao, Han and Jiang. This is an open-access article distributed under the terms of the Creative Commons Attribution License (CC $B Y)$. The use, distribution or reproduction in other forums is permitted, provided the original author(s) and the copyright owner(s) are credited and that the original publication in this journal is cited, in accordance with accepted academic practice. No use, distribution or reproduction is permitted which does not comply with these terms. 